\title{
An accuracy assessment of the CALIOP/CALIPSO version 2/version 3 daytime aerosol extinction product based on a detailed multi-sensor, multi-platform case study
}

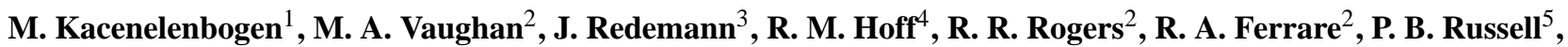 \\ C. A. Hostetler ${ }^{2}$, J. W. Hair ${ }^{2}$, and B. N. Holben ${ }^{6}$ \\ ${ }^{1}$ ORAU/NASA Ames Research Center, Moffett Field, CA, USA \\ ${ }^{2}$ NASA Langley Research Center, Hampton, VA, USA \\ ${ }^{3}$ Bay Area Environmental Research Institute, Sonoma, CA, USA \\ ${ }^{4}$ Joint Center for Earth Systems Technology (JCET)/Goddard Earth Science and Technology Center (GEST), University of \\ Baltimore County, MA, USA \\ ${ }^{5}$ NASA Ames Research Center, Moffett Field, CA, USA \\ ${ }^{6}$ NASA Goddard Space Flight Center, Greenbelt, MA, USA
}

Received: 13 July 2010 - Published in Atmos. Chem. Phys. Discuss.: 16 November 2010

Revised: 30 March 2011 - Accepted: 17 April 2011 - Published: 29 April 2011

\begin{abstract}
The Cloud Aerosol LIdar with Orthogonal Polarization (CALIOP), on board the CALIPSO platform, has measured profiles of total attenuated backscatter coefficient (level 1 products) since June 2006. CALIOP's level 2 products, such as the aerosol backscatter and extinction coefficient profiles, are retrieved using a complex succession of automated algorithms. The goal of this study is to help identify potential shortcomings in the CALIOP version 2 level 2 aerosol extinction product and to illustrate some of the motivation for the changes that have been introduced in the next version of CALIOP data (version 3, released in June 2010). To help illustrate the potential factors contributing to the uncertainty of the CALIOP aerosol extinction retrieval, we focus on a one-day, multi-instrument, multiplatform comparison study during the CALIPSO and Twilight Zone (CATZ) validation campaign on 4 August 2007. On that day, we observe a consistency in the Aerosol Optical Depth (AOD) values recorded by four different instruments (i.e. spaceborne MODerate Imaging Spectroradiometer, MODIS: 0.67 and POLarization and Directionality of Earth's Reflectances, POLDER: 0.58, airborne High Spectral Resolution Lidar, HSRL: 0.52 and ground-based AErosol RObotic NETwork, AERONET: 0.48 to 0.73 ) while CALIOP AOD is a factor of two lower $(0.32$ at $532 \mathrm{~nm})$. This case study illustrates
\end{abstract}

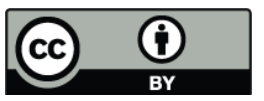

Correspondence to: $\mathrm{M}$. Kacenelenbogen (meloe.s.kacenelenbogen@nasa.gov) the following potential sources of uncertainty in the CALIOP AOD: (i) CALIOP's low signal-to-noise ratio (SNR) leading to the misclassification and/or lack of aerosol layer identification, especially close to the Earth's surface; (ii) the cloud contamination of CALIOP version 2 aerosol backscatter and extinction profiles; (iii) potentially erroneous assumptions of the aerosol extinction-to-backscatter ratio $\left(S_{\mathrm{a}}\right)$ used in CALIOP's extinction retrievals; and (iv) calibration coefficient biases in the CALIOP daytime attenuated backscatter coefficient profiles. The use of version 3 CALIOP extinction retrieval for our case study seems to partially fix factor (i) although the aerosol retrieved by CALIOP is still somewhat lower than the profile measured by HSRL; the cloud contamination (ii) appears to be corrected; no particular change is apparent in the observation-based CALIOP $S_{\mathrm{a}}$ value (iii). Our case study also showed very little difference in version 2 and version 3 CALIOP attenuated backscatter coefficient profiles, illustrating a minor change in the calibration scheme (iv).

\section{Introduction}

The Cloud Aerosol LIdar with Orthogonal Polarization (CALIOP), on board the CALIPSO platform (flying as part of the A-Train satellite constellation since April 2006), is a three-channel elastic backscatter lidar optimized for aerosol

Published by Copernicus Publications on behalf of the European Geosciences Union. 
and cloud profiling. CALIOP measures high-resolution $(1 / 3 \mathrm{~km}$ in the horizontal and $30 \mathrm{~m}$ in the vertical at $532 \mathrm{~nm}$ in low and middle troposphere) profiles of the attenuated backscatter by aerosols and clouds at visible $(532 \mathrm{~nm})$ and near-infrared $(1064 \mathrm{~nm})$ wavelengths along with polarized backscatter in the visible channel (Winker et al., 2009). These data are distributed as part of the level 1 CALIOP products. The level 2 CALIOP products are derived from the level 1 measurements using a complex and intricate succession of algorithms that are described in detail in a special issue of the Journal of Atmospheric and Oceanic Technology (e.g., Winker et al., 2009). The level 2 retrieval scheme is composed of a feature detection scheme, a module that classifies features according to layer type (e.g., cloud vs. aerosol) and sub-type, and, finally, an extinction retrieval algorithm that estimates the aerosol backscatter, the extinction coefficient profile and total column aerosol optical depth (AOD) for an "assumed" (see Sect. 2.2) extinction-to-backscatter ratio (also called $S_{\mathrm{a}}$ ) for each detected aerosol layer.

For a select list of observables, i.e., CALIOP attenuated backscatter, aerosol backscatter and extinction coefficient profiles have been shown to yield reasonable agreement with ground-based (Kim et al., 2008; Mamouri et al., 2009; Mona et al., 2009; Pappalardo et al., 2010) and airborne lidar measurements (McGill et al., 2007; Omar et al., 2009; Rogers et al., 2011). For example, Pappalardo et al. (2010) have observed a mean difference of less than $20 \%$ between level 1 CALIOP and ground-based EARLINET (European Aerosol Research Lidar Network) lidar measurements of attenuated backscatter profiles since June 2006 over Europe, showing an absence of evident biases in the CALIOP raw signals. Rogers et al. (2011) have conducted the most extensive quantitative assessment study of the CALIOP $532 \mathrm{~nm}$ total attenuated backscatter to date, using coincident data from 86 underflights by the NASA-Langley High Spectral Resolution Lidar (HSRL) (Hair et al., 2008) acquired since June 2006. Results show HSRL and CALIOP (version 2) $532 \mathrm{~nm}$ total attenuated backscatter agree within $1.1 \% \pm 23 \%$ for daytime lighting conditions in the free troposphere. Kim et al. (2008) showed that CALIOP, when compared to a ground-based lidar in Korea, has detected cloud and aerosol top/base layers and retrieved the aerosol extinction profiles correctly within respectively $0.10 \mathrm{~km}$ and $30 \%$ in cloud-free nighttime and semitransparent cirrus cloud conditions. According to Omar et al. (2009), CALIOP (version 2) generally overestimates the HSRL extinction measurements for several case studies, with an average extinction bias of $0.003 \mathrm{~km}^{-1}(\sim 24 \%)$ during the CALIPSO and Twilight Zone (CATZ) validation campaign and $0.015 \mathrm{~km}^{-1}(\sim 59 \%)$ during the Gulf of Mexico Atmospheric Composition and Climate Study (GoMACCS).

Nonetheless, there are significant uncertainties associated with the version 2 CALIOP aerosol extinction and backscatter retrievals, and these are not well-quantified in any ancillary quality assurance information included in the level 2 data files. These uncertainties are introduced by several differ- ent factors that are often related to each other (Winker et al., 2009; Yu et al., 2010). First of all, the CALIOP layer detection scheme will most likely fail to detect layers with aerosol backscatter coefficients falling below a sensitivity threshold of $2 \sim 4 \times 10^{-4} \mathrm{~km}^{-1} \mathrm{sr}^{-1}$ in the troposphere (Winker et al., 2009). Consequently, if we assume a lidar extinction-tobackscatter ratio $\left(S_{\mathrm{a}}\right)$ of $50 \mathrm{sr}$, the minimum detectable extinction coefficient is on the order of 0.01 to $0.02 \mathrm{~km}^{-1}$ (corresponding to a lowest detectable AOD of 0.02-0.04 in a homogenous $2 \mathrm{~km}$ planetary boundary layer). A second significant source of error is the lack of photons returned from underneath highly attenuating layers, such as dense aerosol and cloud layers. This may result in the erroneous or total lack of aerosol identification in the lower part of a given profile. In such situations, the CALIOP detection algorithm can incorrectly identify the lower portions of an aerosol layer as being clear air, and thus no aerosol extinction coefficients will be reported for these regions. A third factor impacting the CALIOP extinction retrieval is the occasional misclassification of layer type. Aerosols can be misclassified as clouds, and vice versa (Liu et al., 2009). Classification errors can also occur in the aerosol subtyping algorithm (Omar et al., 2009), leading to an incorrect assumption about the appropriate extinction-to-backscatter ratio. The CALIOP AOD fractional error is similar to the $S_{\mathrm{a}}$ fractional error for small AOD values (Winker et al., 2009). On the other hand, as the AOD increases, the AOD fractional error will quickly become much higher than the $S_{\mathrm{a}}$ fractional error. For example, a fractional error of $30 \%$ for $S_{\mathrm{a}}$ would result in an AOD fractional error of $\sim 50 \%$ for an AOD of 0.5 and nearly $100 \%$ for an AOD of 1.

Despite these uncertainties, there have been a number of publications using CALIOP version 2 level 2 data in a qualitative or even quantitative manner. Focusing on articles published in 2010, some authors recognize the largely unvalidated nature of level 2 version 2 data. Among those, there have been attempts to produce more accurate CALIOP data by applying further cloud-screening (Sekiyama et al., 2010) or even an intensive data screening scheme (Yu et al., 2010). Some mention the uncertainties associated with the level 2 version 2 data but apply no specific filtering (e.g., Peyridieu et al., 2010, Jones and Christopher, 2010). We note that many articles in 2010 (and probably a few more in the previous years) omit discussions on the accuracy of level 2 version 2 CALIOP data. This is, for example, the case for Gonzi and Palmer (2010), who qualitatively compared biomass burning injection height estimates from the GEOS-Chem model to unfiltered CALIOP vertical feature mask data. This latter product is also used to suggest the presence of an extended aerosol layer over central India that could be associated with agriculture crop residue burning activities (Sharma et al., 2010), and to help determine the altitude of smoke plumes over the US during Summer 2006 (McMillan et al., 2010). Finally, Kuhlmann and Quaas (2010) make more intensive use of the unfiltered level 2 CALIOP aerosol layer 
product to draw conclusions regarding the particle type and general aerosol vertical distribution during the Asian summer Monsoon. The conclusions drawn in these works are not necessarily wrong, and, in fact, may be absolutely correct. However, it is difficult to ascertain the merit of the reported results, simply because the data from which they are derived are not yet well validated.

In this study we assess the consistency between the CALIOP AOD retrievals and comparative aerosol observations from multiple sources and platforms (including groundbased, airborne and satellite instruments). We focus on a oneday, multi-sensor case study (Sect. 3) that was part of the nine ground-based CATZ field campaigns (each campaign occurring on separate days between 26 June and 29 August 2007) in Virginia and Maryland, when four AERONET sites were deployed and the NASA Langley Research Center airborne HSRL was flown along the daytime CALIOP track, with coincident space-borne observations available from MODIS and POLDER (Polarization and Directionality of Earth's Reflectances). The detailed suborbital observations, and in particular, the comparison of coincident CALIOP and HSRL profiles, are used to explore the following potential reasons for the overall bias between the MODIS AOD and the CALIOP version 2 AOD product: (i) CALIOP's low signalto-noise ratio (SNR) which can lead to the misclassification and/or lack of aerosol layer identification, especially close to the Earth's surface; (ii) the cloud contamination of CALIOP aerosol backscatter and extinction profiles; (iii) a potentially erroneous $S_{\mathrm{a}}$ assumption in CALIOP's extinction retrieval and (iv) calibration errors in the CALIOP daytime attenuated backscatter coefficient profiles.

We note that this study is not a global validation assessment of the CALIOP version 2/version 3 aerosol extinction product but focuses on one case study. It is not intended to provide a quantitative assessment regarding the generality and magnitude of errors likely to be present in either version of the CALIOP extinction retrieval algorithm. Instead, our study identifies shortcomings in the version 2 level 2 aerosol extinction product and illustrates some of the motivation for the changes that have been introduced in the next version of CALIOP data (Version 3, released in June 2010).

Based on the multi-instrument, multi-platform comparison study, we seek to quantify the major factors potentially contributing to the uncertainty of the CALIOP aerosol extinction retrieval. We then use version 3 CALIOP measurements to assess a potential correction of each of these factors. We submit that the identification and discussion of retrieval uncertainties provided here will help understand and interpret the results obtained in previous studies like the ones cited above.

\section{Instruments}

\subsection{AERONET}

The AErosol RObotic NETwork (AERONET) (Holben et al., 1998) is composed of automatic sun-sky scanning spectral radiometers that determine AOD by direct sun measurements. AERONET measurements also provide the Ångström exponent $(\AA)$, which expresses the wavelength dependence, $\lambda$, of the AOD and is defined as the slope of the first order linear regression of $\log (\mathrm{AOD})$ versus $\log (\lambda)$. The aerosol size distribution and optical parameters (such as the single scattering albedo, volume concentration, refractive index, etc.) are derived from the angular distribution of sky radiances measured in the almucantar according to the algorithm developed by Dubovik and King (2000a). In this study, we use version 2-level 1.5 AERONET data (Smirnov et al., 2002). During the CATZ field experiment, the AERONET sunphotometer observations were sampled more frequently than in the case of the standard automatic mode measurement protocol (Holben et al., 1998), preventing the data from being labeled level 2. However, the correct calibration of the sunphotometers during the experiment results in the same estimated total uncertainty in the direct AOD measurements as for the level 2 data: $\sim 0.010-0.021$ (Eck et al., 1999). In the case of AOD values above 0.2 at $440 \mathrm{~nm}$, Dubovik et al. (2000b) reports accuracies of 0.03 for the single scattering albedo, $0.02-0.04$ for the real part of the refractive index, $30 \%(50 \%)$ of the imaginary part of the refractive index in case of low (high) absorption, 15-35\% (15-100\%) of the volume size distribution in case of a radius between 0.1 and $7 \mu \mathrm{m}$ (lower than $0.1 \mu \mathrm{m}$ or above $7 \mu \mathrm{m}$ ). In the case of lower AOD values $(\operatorname{AOD}(440) \leq 0.2)$, the accuracy levels drop down to $0.05-0.07$ for SSA, $80-100 \%$ for the imaginary part of the refractive index, and 0.05 for the real part of the refractive index.

\subsection{CALIOP}

CALIOP on the CALIPSO platform employs a linearly polarized laser that transmits pulses at $532 \mathrm{~nm}$ and $1064 \mathrm{~nm}$. The two $532 \mathrm{~nm}$ receiver channels separately measure the components of the $532 \mathrm{~nm}$ backscatter signal polarized parallel and perpendicular to the outgoing beam. The measured CALIOP attenuated backscatter coefficient at wavelength $\lambda$ and range $r, \beta_{\lambda}^{\prime}(\mathrm{r})$, can be written as:

$\beta_{\lambda}^{\prime}(r)=\left(\beta_{\mathrm{a}, \lambda}(r)+\beta_{\mathrm{m}, \lambda}(r)\right) T_{\lambda}^{2}(r)$

where $\beta_{\mathrm{a}, \lambda}$ and $\beta_{\mathrm{m}, \lambda}$ are, respectively, the aerosol and molecular backscatter coefficient profile, and $T_{\lambda}^{2}=T_{\mathrm{a}, \lambda}^{2} T_{\mathrm{m}, \lambda}^{2} T_{\mathrm{O}_{3}, \lambda}^{2}$ is the atmospheric two-way transmittance (i.e., signal attenuation) due to aerosols, molecular scattering, and absorbing gases such as ozone. 
Table 1. CALIOP parameters used in this study with attributed name, variable, file, level and horizontal/vertical resolution-version 2 in black and version 3 in red italic. The parameters $\beta_{532}^{\prime} @ 1 / 3 \mathrm{~km}$, cloud @1/3 km, aerosol @5 km and feature @5 km have the same horizontal and vertical resolution in CALIOP version 2 and version 3.

\begin{tabular}{|c|c|c|c|c|c|}
\hline \multirow[t]{2}{*}{ Name } & \multirow[t]{2}{*}{ Variable } & \multirow[t]{2}{*}{ File } & \multirow[t]{2}{*}{ Level } & \multicolumn{2}{|c|}{ Resolution due to averaging } \\
\hline & & & & Horizontal & Vertical $(<8 \mathrm{~km})$ \\
\hline$\beta_{532}^{\prime} @ 1 / 3 \mathrm{~km}$ & Total_Attenuated_Backscatter_532 & CAL_LID_L1-Prov(ValStage1)-V2(V3)-01...hdf & 1 & $1 / 3 \mathrm{~km}$ & $30 \mathrm{~m}$ \\
\hline cloud@1/3 km & Layer_Top_Altitude; Layer_Base_Altitude & CAL_LID_L2_333mCLay-Prov-V2(V3)-01...hdf & 2 & $1 / 3 \mathrm{~km}$ & $30 \mathrm{~m}$ \\
\hline aerosol@5 km & Layer_Top_Altitude; Layer_Base_Altitude & CAL_LID_L2_05 kmALay-Prov-V2(V3)-01...hdf & 2 & $5 \mathrm{~km}$ & $30 \mathrm{~m}$ \\
\hline feature @ $5 \mathrm{~km}$ & Feature_Classification_Flags & CAL_LID_L2_VFM-Prov(ValStage1)-V2(V3)-01...hdf & 2 & $5 \mathrm{~km}$ & $30 \mathrm{~m}$ \\
\hline 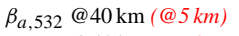 & Total_Backscatter_Coefficient_532 & CAL_LID_L2_40 kmAProCal-Beta-V2(5 kmAPro-Prov-V3)-01... - -hdf & 2 & $40(5) \mathrm{km}$ & $120(60) \mathrm{m}$ \\
\hline 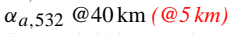 & Extinction_Coefficient_532 & CAL_LID_L2_40 kmAProCal-Beta-V2(5 kmAPro-Prov-V3)-01... -.hdf & 2 & $40(5) \mathrm{km}$ & $120(60) \mathrm{m}$ \\
\hline $\mathrm{S}_{a, 532} @ 40 \mathrm{~km}(@ 5 \mathrm{~km})$ & “ $\alpha_{\mathrm{a}, 532} @ 40(5) \mathrm{km} " / “ \beta_{\mathrm{a}, 532} @ 40(5) \mathrm{km} ”$ & None & 2 & $40(5) \mathrm{km}$ & $120(60) \mathrm{m}$ \\
\hline
\end{tabular}

The two-way aerosol transmittance between the range of the lidar calibration region, $r_{\mathrm{c}}$, and range $r, T_{\mathrm{a}, \lambda}^{2}\left(r_{\mathrm{c}}, r\right)$, can be expressed as follows:

$T_{\mathrm{a}, \lambda}^{2}\left(r_{\mathrm{c}}, r\right)=\exp \left(-2 \int_{r_{\mathrm{c}}}^{r} \alpha_{\mathrm{a}, \lambda}\left(r^{\prime}\right) d r\right)=\exp \left(-2 \tau_{\mathrm{a}, \lambda}\right)$

where $\alpha_{\mathrm{a}, \lambda}$ is the aerosol extinction coefficient and $\tau_{\mathrm{a}, \lambda}$, the aerosol optical depth.

We will be concentrating mostly on the CALIOPmeasured total attenuated backscatter coefficients, $\beta_{532}^{\prime}(\mathrm{r})$, the retrieved aerosol backscatter coefficients, $\beta_{\mathrm{a}, 532}(\mathrm{r})$, and the retrieved aerosol extinction coefficient profiles, $\alpha_{\mathrm{a}, 532}(\mathrm{r})$ along the CALIOP ground track at $532 \mathrm{~nm}$.

The extinction coefficient profiles are retrieved using a globally automated feature recognition algorithm that assumes a range-invariant extinction-to-backscatter ratio, also referred to as lidar ratio $\left(S_{\mathrm{a}, 532}=\alpha_{\mathrm{a}, 532}(\mathrm{r}) / \beta_{\mathrm{a}, 532}(r)\right)$ for each layer detected. The CALIOP value of $S_{\mathrm{a}, 532}$ used for any layer depends on the geographical location, the integrated attenuated backscatter color ratio, the layer-integrated volume depolarization ratio, and a general look up table (LUT) (Liu et al., 2009; Omar et al., 2009). The "assumed" CALIOP lidar ratio in this study is, in fact, selected after several steps including the subtype classification of each detected aerosol layer, based itself on an extensive clustering analysis of global AERONET measurements. The prelaunch goal of the CALIPSO mission was to retrieve aerosol extinction coefficients accurate to within $\pm 40 \%$ (Winker et al., 2003). We have attributed names to all the CALIOP parameters used in this study. They are listed in Table 1 along with the standard variables, original file name, level, and spatial resolution due to averaging for CALIOP's version 2 and version 3 data products. We emphasize that this study is mainly focused on the CALIOP version 2 extinction products. CALIOP version 3 data products are used specifically to address whether the new CALIOP algorithm fixes certain issues identified in version 2.

CALIOP's version 2 data products do not provide uncertainty estimates for retrieved optical parameters such as AOD and extinction coefficients (see CALIPSO Version 2 Data Quality Statements). The uncertainties attributed to the
CALIOP aerosol optical depths can be obtained by applying an error estimator algorithm to the quantities reported in the aerosol layer products, taking into account the relative error on the lidar ratio, the calibration coefficient and the SNR for each detected aerosol layer. The error in the extinction retrieval due to the SNR may be slightly more complex to estimate as it depends on the backscatter intensity, the lighting conditions (i.e., day vs. night), and the amount of horizontal averaging applied to the initial attenuated backscatter profiles.

\subsection{HSRL}

Retrieval of aerosol extinction profiles using the standard elastic backscatter lidar technique requires either a measurement of AOD to constrain the extinction retrieval (Young, 1995; McGill et al., 2003) or an assumption on the aerosol extinction-to-backscatter ratio value (Cattrall et al., 2005). On the other hand, the HSRL technique directly measures the vertical profile of aerosol extinction and extinction-tobackscatter ratio, without requiring ancillary aerosol measurements or assumptions about aerosol type (Hair et al., 2008). The HSRL technique is typically employed for the $532 \mathrm{~nm}$ wavelength utilizing the iodine vapor filter technique (Hair et al., 2001, 2008; Piironen and Eloranta 1994). The received $532 \mathrm{~nm}$ backscatter return is split between two optical channels to discriminate between aerosol and molecular returns: (1) one passing through an iodine vapor cell which absorbs the central portion of the backscatter spectrum, including all of the Mie backscatter, and transmits only the Doppler/pressure-broadened molecular backscatter (called the "molecular channel"); and (2) another one that passes all frequencies of the signal returned by both aerosols and molecules (called the "total scatter channel"). In addition, the lidar is polarization-sensitive, enabling discrimination between spherical and non-spherical particles. The first channel ("molecular channel") is used to retrieve the extinction profile and both channels are used to retrieve profiles of aerosol backscatter and extinction coefficients and aerosol depolarization ratios. Hair et al. (2008) described the potential errors introduced in any of these quantities and found the $532 \mathrm{~nm}$ extinction systematic errors to be less than $0.01 \mathrm{~km}^{-1}$ 
Table 2. HSRL parameters used in this study with attributed name, variable and short description.

\begin{tabular}{lll}
\hline & & HSRL data (subset file: $\sim 4 / 3 \mathrm{~km}$ horizontal and $30 \mathrm{~m}$ vertical resolution) \\
\hline Name & Variable & Description (at $532 \mathrm{~nm})$ \\
\hline$\beta_{532}^{\prime}$ & 532_total_attn_bsc_cloud_screened & $\begin{array}{l}\text { Attenuated backscatter coefficient with cloud mask applied } \\
\text { Reported from } \sim 60 \mathrm{~m} \text { to } \sim 1.5 \mathrm{~km} \text { below the plane }(\sim 7.5 \mathrm{~km})\end{array}$ \\
\hline$\beta_{\mathrm{a}, 532}$ & 532_bsc_cloud_screened & $\begin{array}{l}\text { Aerosol volume backscatter coefficient with cloud mask applied } \\
\text { Reported from } \sim 60 \mathrm{~m} \text { to } \sim 0.5 \mathrm{~km} \text { below the plane }(\sim 8.5 \mathrm{~km})\end{array}$ \\
\hline$\alpha_{\mathrm{a}, 532}$ & 532_ext & $\begin{array}{l}\text { Retrieved } 532 \mathrm{~nm} \text { aerosol extinction coefficient. } \\
\text { Reported from } \sim 360 \mathrm{~m} \text { to } \sim 2.5 \mathrm{~km} \text { below the plane }(\sim 6.4 \mathrm{~km})\end{array}$ \\
\hline $\mathrm{S}_{\mathrm{a}, 532}$ & Sa_532 & $\begin{array}{l}\text { Retrieved Extinction-to-backscatter ratio } \\
\text { Reported from } \sim 360 \mathrm{~m} \text { to } \sim 2.5 \mathrm{~km} \text { below the plane }(\sim 6.4 \mathrm{~km})\end{array}$ \\
\hline $\mathrm{AOD}_{532}$ & AOT_hi & $\begin{array}{l}\text { Aerosol optical thickness determined from the molecular } \\
\text { channel near the aircraft and near the surface } \\
\text { Derived from } \sim 60 \mathrm{~m} \text { to } \sim 2.5 \mathrm{~km} \text { below the aircraft }(\sim 6.4 \mathrm{~km})\end{array}$ \\
\hline
\end{tabular}

for typical aerosol loading. Table 2 describes the HSRL analyzed data products used in this study. We use an HSRL subset file with a $\sim 4 / 3 \mathrm{~km}$ horizontal and $30 \mathrm{~m}$ vertical resolution. On the one hand, the $\sim 4 / 3 \mathrm{~km}$ horizontal resolution of the HSRL aerosol backscatter coefficient profiles is obtained by computing $10 \mathrm{~s}$ running averages of the raw data (initially sampled at $2 \mathrm{~Hz}$ ), then sub-sampling the results by a factor of 20 . On the other, the $\sim 4 / 3 \mathrm{~km}$ horizontal resolution of the HSRL extinction and lidar ratio coefficient profiles is obtained by computing 60 second running averages of the raw data.

\subsection{POLDER and MODIS}

POLDER-3 (POLarization and Directionality of Earth's Reflectances, the third version of the POLDER instruments, on board the PARASOL platform) and MODIS (on board the Earth Observing System (EOS) AQUA satellite) are both passive radiometers, with both platforms being part of the A-Train during five years (December 2004-2009), including our study period of Summer 2007. POLDER's strength is the measurement of directional and polarized characteristics of the solar radiation reflected by the Earth-Atmosphere system. MODIS, on the other hand, has a finer spatial and spectral resolution. POLDER AOD estimates of polarizing particles over land surfaces are retrieved in the $865 \mathrm{~nm}$ channel. MODIS AOD is retrieved over oceans in 7 different spectral bands $(6+1$ extrapolated) from the visible to the near infrared and over land in 3 bands $(2+1$ interpolated). POLDER's spatial resolution is $5 \times 6.5 \mathrm{~km}$ $(500 \times 500 \mathrm{~m}$ for most MODIS channels) and its wide field of view induces a $1600 \mathrm{~km}$ swath (2330 km for MODIS) that allows a nearly global daily coverage. To increase the signal to noise ratio, the standard retrieval algorithm is applied to $3 \times 3$ POLDER pixels $(20 \times 20$ for MODIS $)$, leading to a resolution in the aerosol AOD of $15 \times 19.5 \mathrm{~km}(10 \times 10 \mathrm{~km}$ for MODIS at nadir). The AOD retrieval from the POLDER polarized measurements is described by Deuzé et al. (2001) and the MODIS AOD retrieval algorithm over land is described in Kaufmann and Tanré (1998). The polarization by aerosols mainly comes from small spherical particles in the accumulation mode (Vermeulen et al., 2000), indicating that POLDER-derived AOD is well suited for remote sensing of fine mode particles. Validation studies suggest that the expected uncertainty on the MODIS AOD over dark land surfaces could be represented by $\triangle \mathrm{AOD}= \pm 0.05 \pm 0.15 \mathrm{AOD}$ (Levy et al., 2010).

\section{Evaluation of Version 2 CALIOP extinction retrieval: 4 August 2007 (A CATZ case study)}

\subsection{Aerosol type and sources}

The MODIS true color RGB image in Fig. 1a shows some haze hovering over a significant part of the Mid-Atlantic East Coast of the United States, extending from Virginia to New Jersey on 4 August 2007. This particle plume is most likely a mix of aerosol pollution from regional anthropogenic sources and smoke coming from wildfires in the Northwestern United States. According to the National Interagency Fire Center, more than a dozen large fires were reported from late July to early August of 2007 in the Northern Rockies of Idaho and Montana. By 07 August, those fires had affected nearly 400000 acres in Idaho and had produced smoke that blanketed much of the United States. The 3 day-HYSPLIT air mass back-trajectories at three different heights from 500 to $1500 \mathrm{~m}$ (Draxler et al., 2010; Rolph, 2010) (Fig. 1a), suggests that a part of the aerosol plume over the East Coast on 
Table 3. 4 August 2007 - Distance $(\mathrm{km})$ between the different measurements during the CATZ experiment; from top to bottom, the CATZSanders AERONET station (white diamond, Fig. 2a), the closest point on the HSRL track to CATZ-Sanders (green line, Fig. 2a), the closest point on the CALIOP ground track to CATZ-Sanders (white line, Fig. 2a), the closest CMAQ cell to CATZ-Sanders containing a MODIS and CALIOP version 2 AOD value (red box, Fig. 2a) and the closest CMAQ cell to CATZ-Sanders containing a POLDER AOD retrieval (black box, Fig. 2a).

\begin{tabular}{lllll}
\hline Distance $(\mathrm{km})$ & CATZ_Sanders & $\begin{array}{l}\text { Closest point on } \\
\text { HSRL track }\end{array}$ & $\begin{array}{l}\text { Closest point on } \\
\text { CALIOP track }\end{array}$ & $\begin{array}{l}\text { CMAQ cell with } \\
\text { CALIOP/MODIS AOD }\end{array}$ \\
\hline CATZ_Sanders & & - & - & - \\
Closest point on HSRL track & 0.940 & - & - & - \\
Closest point on CALIOP track & 0.138 & 0.908 & - & - \\
CMAQ cell with CALIOP/MODIS AOD & 5.809 & 5.315 & 5.680 & - \\
CMAQ cell with POLDER AOD & 17.703 & 17.339 & 17.569 & 12.067 \\
\hline
\end{tabular}

4 August 2007 may have come from the Northern part of the United States.

We will be focusing our study over the CATZ-Sanders Elementary School AERONET station $\left(39.04^{\circ} \mathrm{N} ;-77.51^{\circ} \mathrm{W}\right)$, one of the four sunphotometer sites that were deployed along the CALIOP track during the CATZ campaign. This station, shown by a white diamond in Fig. 1a, will hereafter be called "CATZ-Sanders". CATZ-Sanders was $138 \mathrm{~m}$ away from the CALIOP track and the overpass on 4 August occurred at 18:27 UTC. Aerosol microphysical and optical properties derived from the inversion of two angular sky-radiance measurements at CATZ-Sanders on 4 August 2007 are shown in Fig. $1 b$.

The aerosol plume over CATZ-Sanders seems predominantly composed of fine particles, with Ångström coefficients ( $\AA$ between $440-870 \mathrm{~nm}$ ) of 1.92 (Fig. 1b). This is confirmed by the volume size distributions that show, for both measurements, a peak around $0.16 \mu \mathrm{m}$ in radius. Finally, the particles show significant light absorption with a single scattering albedo coefficient $\left(\omega_{0}\right)$ between 0.94 and 0.96 and an imaginary part of the refractive index $(\operatorname{Im}(\eta))$ of about 0.01 .

\subsection{Ground-based, airborne and space-borne AOD measurements}

In this study, for convenience, all satellite data are remapped on the $12 \times 12 \mathrm{~km}$ Community Multiscale Air Quality (CMAQ) model grid (US EPA, 1999). Each MODIS $10 \times 10 \mathrm{~km}$ cell center has been attributed to the closest CMAQ cell center. In the case of CALIOP, the product to be remapped is the standard level 2 extinction coefficient, $\alpha_{\mathrm{a}, 532} @ 40 \mathrm{~km}$ (see Table 1). CALIOP provides one constant extinction vertical profile between start-location $1_{\text {start }}$ and end-location $l_{\text {end }}$, with a horizontal distance of $40 \mathrm{~km}$ between $l_{\text {start }}$ and $l_{\text {end }}$. A $12 \times 12 \mathrm{~km}$ CMAQ cell can then contain, at the most, two different parts of $\alpha_{\mathrm{a}, 532} @ 40 \mathrm{~km}$ profiles. When the CMAQ cell contains only one $\alpha_{\mathrm{a}, 532} @ 40 \mathrm{~km}$ profile, this profile is simply attributed to the cell's center; on the other hand, when the cell contains two differ- ent $\alpha_{\mathrm{a}, 532} @ 40 \mathrm{~km}$ profiles, the final profile attributed to the cell's center is an average of those two $\alpha_{\mathrm{a}, 532} @ 40 \mathrm{~km}$ profiles weighted by the number of corresponding $\beta_{532}^{\prime} @ 1 / 3 \mathrm{~km}$ profiles contained in the cell. The CALIOP AOD data value for each cell is then obtained by integrating its corresponding $\alpha_{\mathrm{a}, 532} @ 40 \mathrm{~km}$ profile vertically.

Figure 2a shows the locations of CATZ-Sanders (white diamond), the CALIOP ground track along the closest $40 \mathrm{~km}$ segment (white line), the corresponding airborne HSRL track segment (green line) and the closest CMAQ $12 \times 12 \mathrm{~km}$ cell (red box). Recall that all satellite data are remapped onto the CMAQ grid and the closest CMAQ cell to CATZSanders (red box in Fig. 2a) contains a remapped MODIS and CALIOP AOD observation. On the other hand, the closest CMAQ cell with available POLDER AOD data on $4 \mathrm{Au}-$ gust 2007 is shown as a black box in Fig. 2a, at a distance of $\sim 18 \mathrm{~km}$ between CATZ-Sanders and the closest POLDER extinction observation. Table 3 summarizes the horizontal distances between each measurement during the experiment.

Figure $2 \mathrm{~b}$ shows the collocated ground-based (sunphotometer, black), airborne (HSRL, orange) and space-borne (MODIS green, POLDER red and CALIOP blue) AOD observations. The sunphotometer is the only instrument providing a full temporal evolution of AOD values throughout the afternoon and evening of 4 August 2007. The HSRL instrument completes this temporal information with two overpasses over CATZ-Sanders around 16:48 and 17:52 UTC.

It should be noted that HSRL overflew CATZ-Sanders $\sim 30$ min before CALIPSO overpass time (17:52 UTC compared to 18:27 UTC for CALIPSO) and $\sim 900 \mathrm{~m}$ away from the CALIOP ground-track (Table 3). A ground-based wind profiler instrument in Beltsville (Maryland) shows an average wind speed of $\sim 2.6 \mathrm{~m}$ per second from the surface up to $\sim 3.8 \mathrm{~km}$ between the HSRL and CALIOP overpass time, blowing mainly from the northwest. Accordingly, a 30-min air mass travel time between the HSRL and CALIOP observations would represent a distance of roughly $5 \mathrm{~km}$ at the ground. 

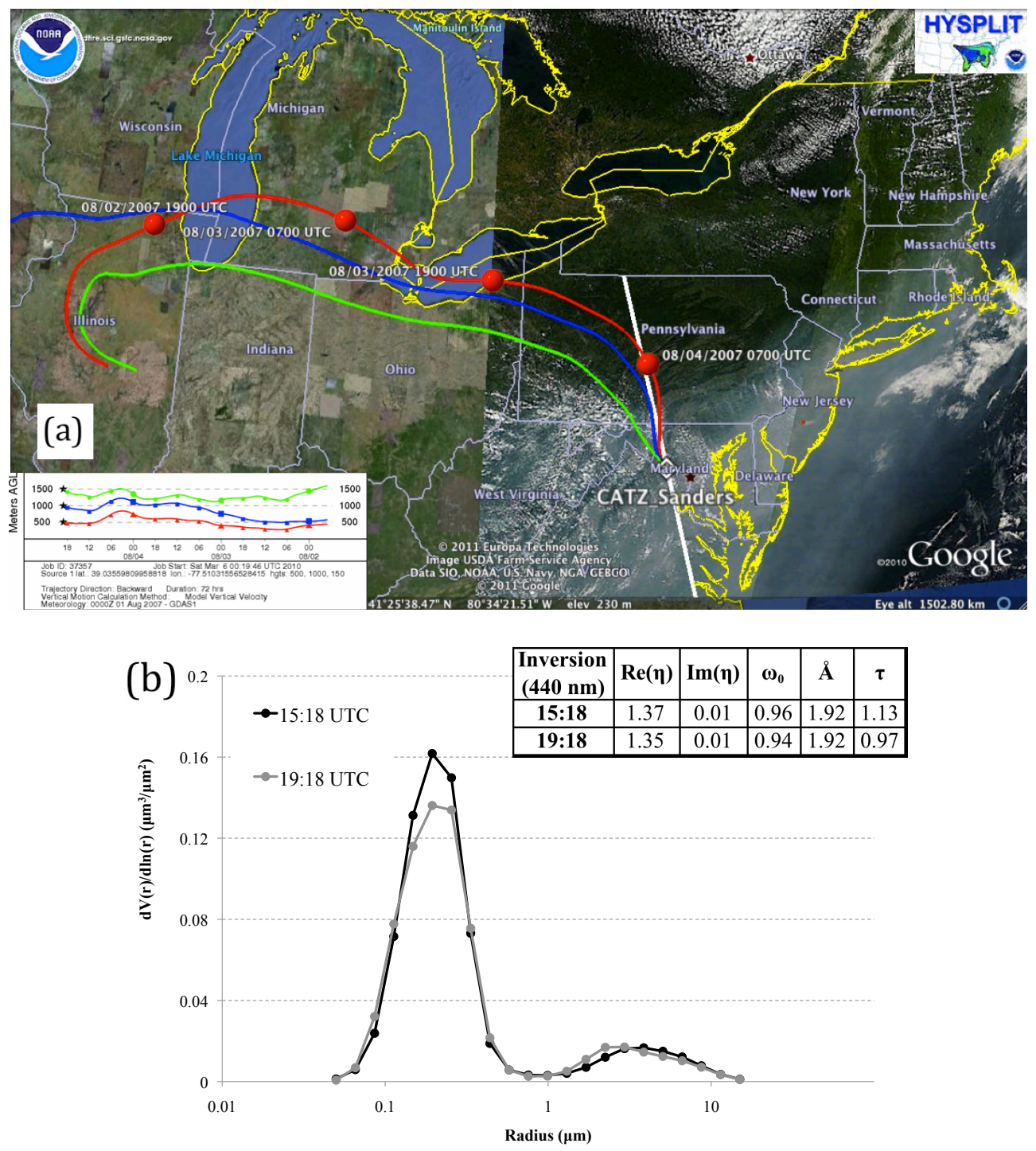

Fig. 1. 4 August 2007 - (a) MODIS true color RGB image over the East Coast of the United States, 72 h-HYSPLIT air mass back-trajectories at 500 (red), 1000 (blue) and 1500 (green) meters above model ground level arriving at 19:00 UTC over CATZ-Sanders (white diamond) and the CALIOP ground track (white line); the back-trajectories are computed using the gridded meteorological data archives of the National Weather Service's (NWS) National Centers for Environmental Prediction (NCEP) Global Data Assimilation System (GDAS) model; (b) Version 2-level 1.5 CATZ-Sanders AERONET observations derived from the angular distribution of sky radiance in the almucantar (2 measurements).

Whether it is statistically relevant to compare AOD retrievals from HSRL and CALIOP on that time $(\sim 30 \mathrm{~nm})$ and horizontal scale $(\sim 5 \mathrm{~km})$ is difficult to ascertain. The autocorrelation of either the HSRL AOD or the CALIOP AOD dataset for different lagged distances along the flight or the satellite track could help inform on a relevant comparison distance. For CALIOP and HSRL, the distances of interest to this study (a few tens of kilometers) would likely be sampled in a short enough time that it would be reasonable to neglect temporal evolution of the aerosols. On another hand, the statistical relevance of comparing HSRL and CALIOP on a 30-min time scale could be partially informed by the au- tocorrelation coefficient of the CATZ-Sanders ground-based AERONET AOD values for different lagged times.

Instead of performing the studies described above, we refer to (Anderson et al., 2003) that uses datasets from four different instruments (two ground-based, one airborne and one space-borne) to show a reasonably coherent picture of mesoscale aerosol variations: when measured at one local point, scales below $4.4 \mathrm{~h}$ or $70 \mathrm{~km}$ show large autocorrelation coefficients ( $R$ above 0.90$)$, indicating both small ambient variability and measurement noise. Redemann et al. (2006) shows similar results $(R=0.96)$ on a scale of $15 \mathrm{~km}$ for the AOD derived from the NASA Ames Airborne Tracking 
Sunphotometer (AATS-14) during the Extended-MODIS- $\lambda$ Validation Experiment (EVE) campaign in April of 2004.

The relevance of a $30 \mathrm{~min}$ and $5 \mathrm{~km}$ spatio-temporal scale between CALIOP and HSRL AOD also varies from one environment to another. In our case study, according to Fig. 2b, there is a fair amount of variation in the AERONET AOD measurements throughout the afternoon and evening of 4 August 2007 (from 0.48 to 0.87 at $532 \mathrm{~nm}$ ). The variation $\pm 1 / 2 \mathrm{~h}$ around the time of the A-Train overpass is smaller but still significant, with AOD values (at $532 \mathrm{~nm}$ ) ranging from 0.48 to 0.73 . This variation, similar to the range of AOD $1 / 2 \mathrm{~h}$ preceding the A-Train overpass, corresponds to a change of $\sim 35 \%$ in the AOD ( 0.25 compared to 0.71 at the A-train overpass time) over a course of $\sim 5 \mathrm{~km}$ (distance covered by the air mass in $1 / 2 \mathrm{~h}$ with an averaged wind speed of $\sim 2.6 \mathrm{~m} / \mathrm{s}$ ). The temporal variability of midvisible AOD during our case study of 4 August 2007 falls in the AATS14 spatial AOD variability range (2-37\%) observed along most $6 \mathrm{~km}$-segments through an environment dominated by biomass-burning plumes over Canada during the ARCTAS field campaign (Arctic Research of the Composition of the Troposphere from Aircraft and Satellites) (Shinozuka et al., 2010). In addition, the effect of vertical mixing could either decrease or increase variability in remotely sensed total column AOD observations as well as profiles of aerosol extinction properties.

The HSRL AOD retrieval (0.52) agrees with the AERONET direct-beam AOD measurement (0.57), showing a slight difference of 0.05 at the time of the second HSRL overpass ( 18:00 UTC).

At the time of the A-train overpass (dashed vertical line in Fig. 2b), MODIS and AERONET report similar AOD retrieval values (with a difference of 0.04 , below MODIS's AOD uncertainty of $\sim 0.15,0.05+15 \%$ of 0.67 ). On the other hand, POLDER underestimates the AERONET AOD by 0.13 . This slight difference could be due to uncertainties in the POLDER inversion algorithm. Some bias could also be due to the satellite's coarse spatial resolution in a temporally and spatially varying aerosol field, especially for POLDER with a coarser resolution than MODIS and further away from the sunphotometer (Table 3). Recall that POLDER is sensitive to fine polarizing particles over land and, thus, retrieves the fine mode AOD when MODIS retrieves the AOD corresponding to the entire volume size distribution of the particles (see Fig. 1b).

In conclusion, all three AOD observations [i.e., MODIS (0.67), POLDER (0.58) and HSRL (0.52)] are contained in the AERONET AOD envelope within $1 / 2 \mathrm{~h}$ around the ATrain overpass ( 0.48 to 0.73 at $532 \mathrm{~nm}$ ). The CALIOP version 2 AOD value (0.32), however, is well below the range of all other AOD measurements in Fig. $2 b$.

A broader comparison between version 2-derived CALIOP AOD and collocated MODIS AOD retrievals (both on the CMAQ grid) over the Continental United States during the summer of 2007 yielded (results not shown here) a similar mean underestimation by CALIOP. The best statistical agreement between those two quantities was found over the Eastern part of the United States with, nonetheless, a weak correlation $(R \sim 0.4)$ and an apparent CALIOP version 2 underestimation (by $\sim 66 \%$ ) of MODIS AOD.

In the following section, we investigate the potential reasons for a disagreement between the AOD calculated from CALIOP's version 2 extinction product and the rest of the AOD measurements in Fig. 2b.

\subsection{HSRL and CALIOP backscatter and extinction coefficient profiles}

Figure 3 shows the CALIOP and HSRL $\beta_{532}^{\prime}$ cross sections of attenuated backscatter (also called "curtain scene") along the $40 \mathrm{~km}$ segment of their ground tracks close to CATZSanders (respectively corresponding to the white and green lines in Fig. 2a). Both CALIOP and HSRL are shown at a horizontal resolution of $\sim 4 / 3 \mathrm{~km}$ (output resolution of the "subset" HSRL file and sliding average of four CALIOP $\beta_{532}^{\prime} @ 1 / 3 \mathrm{~km}$ profiles). A dashed black vertical line in all three panels shows the closest profile to CATZ-Sanders on 4 August 2007.

The difference between the CALIOP "curtain scenes" shown in Fig. 3a and b reflects an additional cloud-screening of the data. Yost et al. (2008) compared MODIS images overlaid with the CALIOP cloud @ $1 / 3 \mathrm{~km}$ product, and the feature @ $5 \mathrm{~km}$ product. It was shown that the CALIOP 1/3$\mathrm{km}$ detection results are entirely consistent with the MODIS image. However, in regions populated by broken boundary layer clouds, layers detected at coarser resolutions (1$\mathrm{km}$ and above) are frequently misclassified as cloud. This was determined to be strictly a coding error in the cloudclearing procedure, and not related to the algorithm design. To circumvent this error, in this part of our study, an additional cloud screening has been applied to all CALIOP $\beta_{532}^{\prime} @ 1 / 3 \mathrm{~km}$ profiles using the cloud @ $1 / 3 \mathrm{~km}$ product: all CALIOP $\beta_{532}^{\prime} @ 1 / 3 \mathrm{~km}$ coefficients are deleted underneath the highest detected cloud in the cloud @ $1 / 3 \mathrm{~km}$ product.

The black circle in Fig. 3a, b and c points out a region of the curtain scene showing high initial raw $\beta_{532}^{\prime} @ 1 / 3 \mathrm{~km}$ coefficient values around $2.2 \mathrm{~km}$ on the vertical (Fig. 3a). This signal is classified as a cloud in the cloud @ $1 / 3 \mathrm{~km}$ product and is removed in Fig. 3b, thanks to the additional cloud screening described above. In Fig. 3b, the sliding average of four profiles in the curtain scene (for an end horizontal resolution of $4 / 3 \mathrm{~km}$ ) prevents us from observing a lack of data underneath the detected cloud, where all $\beta_{532}^{\prime} @ 1 / 3 \mathrm{~km}$ coefficients were removed. Figure $3 \mathrm{c}$ shows a lack of HSRL data in the corresponding region, most probably due to the presence of clouds as well (the HSRL data are cloud-screened, see Table 2).

Figure 3 illustrates the differences in the SNR of the HSRL and CALIOP instruments. The CALIOP curtain scene 

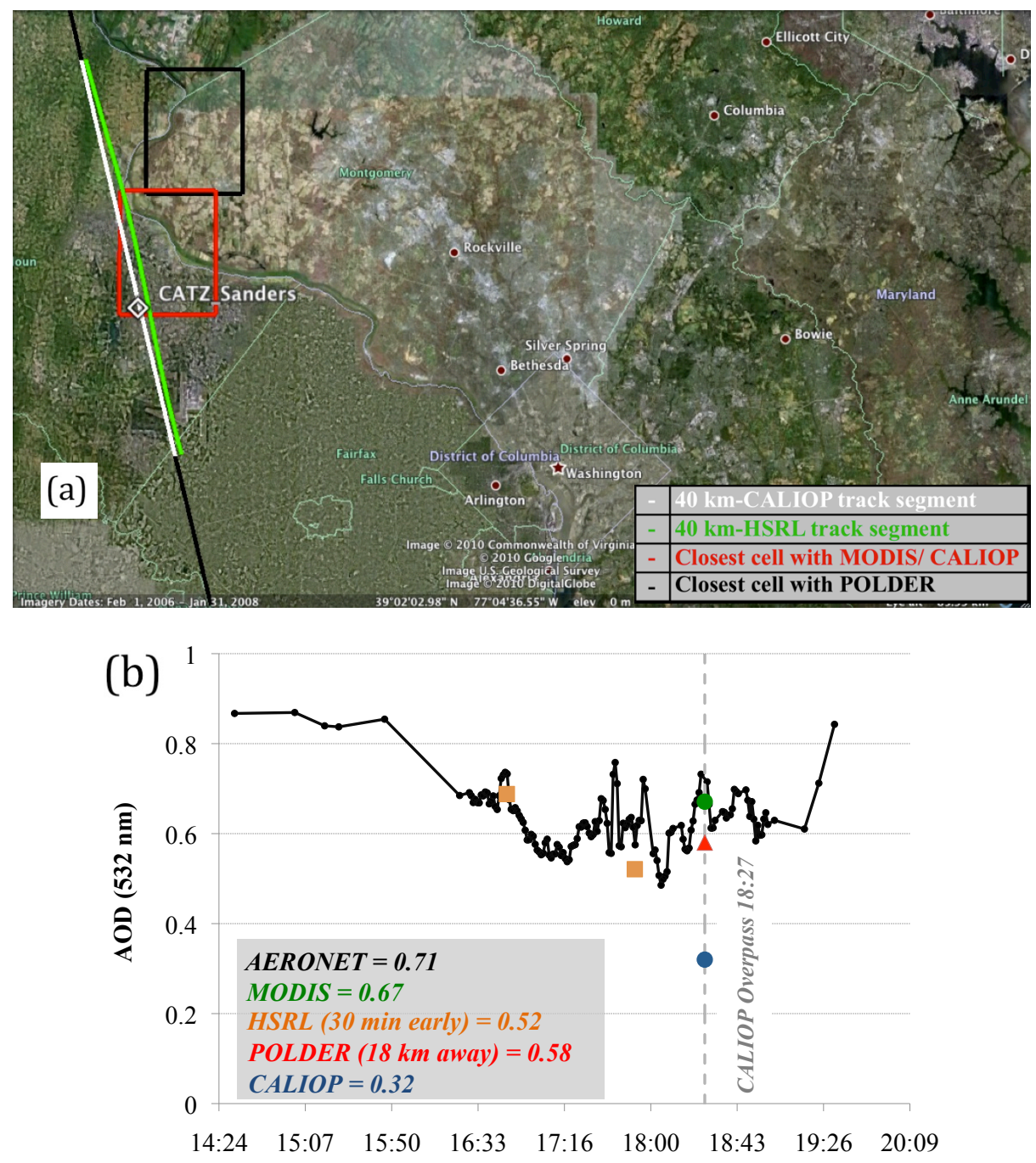

Time (UTC)

Fig. 2. 4 August 2007 - (a) Co-localization of CATZ-Sanders (white diamond), the closest $40 \mathrm{~km}-\mathrm{CALIOP}$ track segment (white line), the corresponding closest $40 \mathrm{~km}$-HSRL track segment (green line), the $12 \times 12 \mathrm{~km}$ closest CMAQ cell (red box) reporting available MODIS and CALIOP version 2 AOD data and the closest CMAQ cell reporting available POLDER AOD data (black box); (b) Temporal evolution of AERONET CATZ-Sanders direct sun AOD measurements (black) and the collocated HSRL AOD retrievals during the two overpasses (AOD $_{532}$ of Table 2, orange); At the time of the A-Train overpass (18:27 UTC, dotted grey line) over CATZ-Sanders: in green, the MODIS AOD retrieval (red box of (a)), in red, the POLDER AOD value (black box of (a)) and in blue, the CALIOP version 2 AOD value (red box of (a)). All AOD observations are either retrieved or computed at $532 \mathrm{~nm}$ (use of the Ångström exponent between 440-675 nm, 470-670 nm and 865-670 $\mathrm{nm}$ for AERONET, MODIS and POLDER).

(Fig. 3b) appears much noisier than the HSRL cross section (Fig. 3c), which makes it harder to analyze in terms of potential atmospheric vertical composition. On the other hand, Fig. 3c seems to show two fairly separate and spatially homogeneous stronger regions in the $\beta_{532}^{\prime}$ intensity on the vertical: the lowest one lies roughly between 1 and $2 \mathrm{~km}$ and the uppermost one is around $3 \mathrm{~km}$. In addition, the closest point to CATZ-Sanders on the HSRL track (black dashed line in Fig. 3c) seems fairly representative of the rest of the $40 \mathrm{~km}$ curtain scene.
Figure $4 \mathrm{a} 2$ shows the most closely collocated version 2 CALIOP and HSRL $\beta_{532}^{\prime}$ profile to CATZ-Sanders (black dashed line in Fig. 3b and c). Both CALIOP (Fig. 4a2, blue) and HSRL (Fig. 4a2, red) profiles are shown at a $\sim 4 / 3 \mathrm{~km}$ resolution (output resolution of the HSRL subset file and selection of the closest CALIOP profile in the $4 / 3 \mathrm{~km}$-resolution curtain scene of Fig. 3b). The CALIOP $\beta_{532}^{\prime}$ profile still clearly shows a very low SNR compared to the HSRL $\beta_{532}^{\prime}$ profile. 

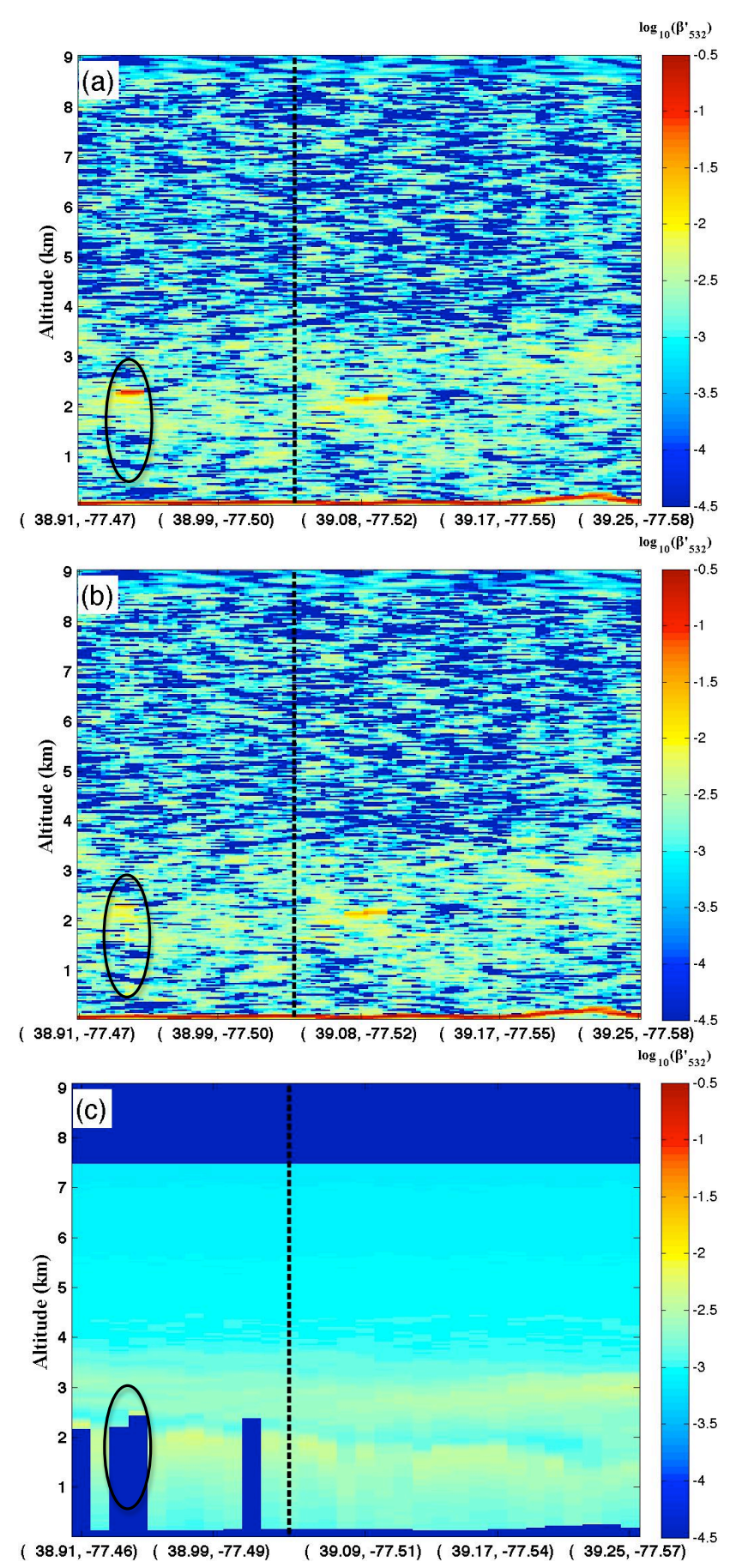

Fig. 3. 4 August 2007 - CALIOP version 2 raw (a), CALIOP version 2 with further cloud-screening (b) and HSRL (c) $\beta_{532}^{\prime}$ curtain scene along the $40 \mathrm{~km}$ segment of its ground tracks close to CATZSanders (respectively white and green line in Fig. 2a). Both CALIOP and HSRL are shown at a $\sim 4 / 3 \mathrm{~km}$ resolution; the black circles in (a), (b) and (c) point out a region with cloud contamination.
CALIOP's low SNR (as shown in Figs. 3b and 4a), especially in daytime, requires spatial averaging of the attenuated backscatter profile over a significant horizontal distance to detect potential features. This is one of the tasks of the Selective Iterated BoundarY Locator (SIBYL) in CALIOP's automated level 2 product routine (Vaughan et al., 2009). In short, SIBYL consists of an algorithm that iteratively averages profiles at different horizontal scales $(5,20$ or $80 \mathrm{~km})$, scans those averaged profiles to detect aerosol and cloud layers, and removes detected layers from the profiles before further averaging. As a result, strongly scattering layers and portions of layers are detected at finer spatial resolution, while more tenuous regions are detected at coarser resolutions. All layers detected are then classified according to type and subtype (Liu et al., 2009; Omar et al., 2009). Particulate backscatter and extinction coefficients are then derived for each layer detected at the $5-\mathrm{km}, 20-\mathrm{km}$, and $80-\mathrm{km}$ averaging interval, using profiles of $\beta^{\prime}(z)$ averaged horizontally to the spatial resolution at which the layer was detected (Young and Vaughan, 2009). In CALIPSO's version 2 data products, the level 2 "native resolution" $\beta_{\mathrm{a}, 532}$ and $\alpha_{\mathrm{a}, 532}$ profiles are further averaged (layers detected at $5-\mathrm{km}$ or $20-\mathrm{km}$ ) or replicated (80-km layers) as required to be reported at a uniform final resolution of $40 \mathrm{~km}$ horizontal and $120 \mathrm{~m}$ vertical (Table 1).

The closest version $2 \beta_{\mathrm{a}, 532} @ 40 \mathrm{~km}$ profile to CATZSanders is shown in Fig. $4 \mathrm{~b} 2$ (black), along with the collocated HSRL $\beta_{\mathrm{a}, 532}$ profile (red). Unlike the processing of CALIOP profiles, we saw no necessity to average the HSRL profiles on a similar horizontal distance at the ground because of HSRL's considerably higher SNR and accuracy. Figure 3c supports this decision by showing a spatially uniform atmospheric HSRL curtain scene in the vicinity of CATZ-Sanders. In addition, the HSRL would cover $40 \mathrm{~km}$ in a few minutes (HSRL flies at $\sim 117 \mathrm{~m} / \mathrm{s}$ ) compared to a few seconds for CALIOP (flies at $\sim 7 \mathrm{~km} / \mathrm{s}$ ), adding potential temporal differences in the HSRL-CALIOP comparison.

In Fig. 4b2, the CALIOP $\beta_{\mathrm{a}, 532} @ 40 \mathrm{~km}$ profile reports no aerosol above $\sim 3.2 \mathrm{~km}$ or below $\sim 1.4 \mathrm{~km}$. Both the CALIOP $\beta_{\mathrm{a}, 532} @ 40 \mathrm{~km}$ and the HSRL $\beta_{\mathrm{a}, 532}$ profile seem to show mostly two intensity peaks in the vertical. The change in intensity between the uppermost and the lowest peak could be due to either a change in the particle type (size and shape, hence different aerosol cross section and phase function) and/or a change in the particle concentration, and does not necessarily show two vertically separated aerosol layers. Concerning the uppermost aerosol peak, the HSRL and CALIOP signals compare fairly well between 2.3 and $3.2 \mathrm{~km}$. In Table 4, the standard aerosol @ $5 \mathrm{~km}$ product (Table 1), shows that the uppermost aerosol layer in version 2 (detected at a horizontal averaging of $20 \mathrm{~km}$ ) is located between 2.7 and $3.1 \mathrm{~km}$, and defines it as polluted dust aerosol particles (CALIOP model $S_{\mathrm{a}}=65 \mathrm{sr}$ ). The lowest intensity peak in Fig. $4 \mathrm{~b} 2$ consists of a fairly constant portion of the HSRL $\beta_{\mathrm{a}, 532}$ profile recording roughly $0.003 \mathrm{~km}^{-1} \mathrm{sr}^{-1}$ from 

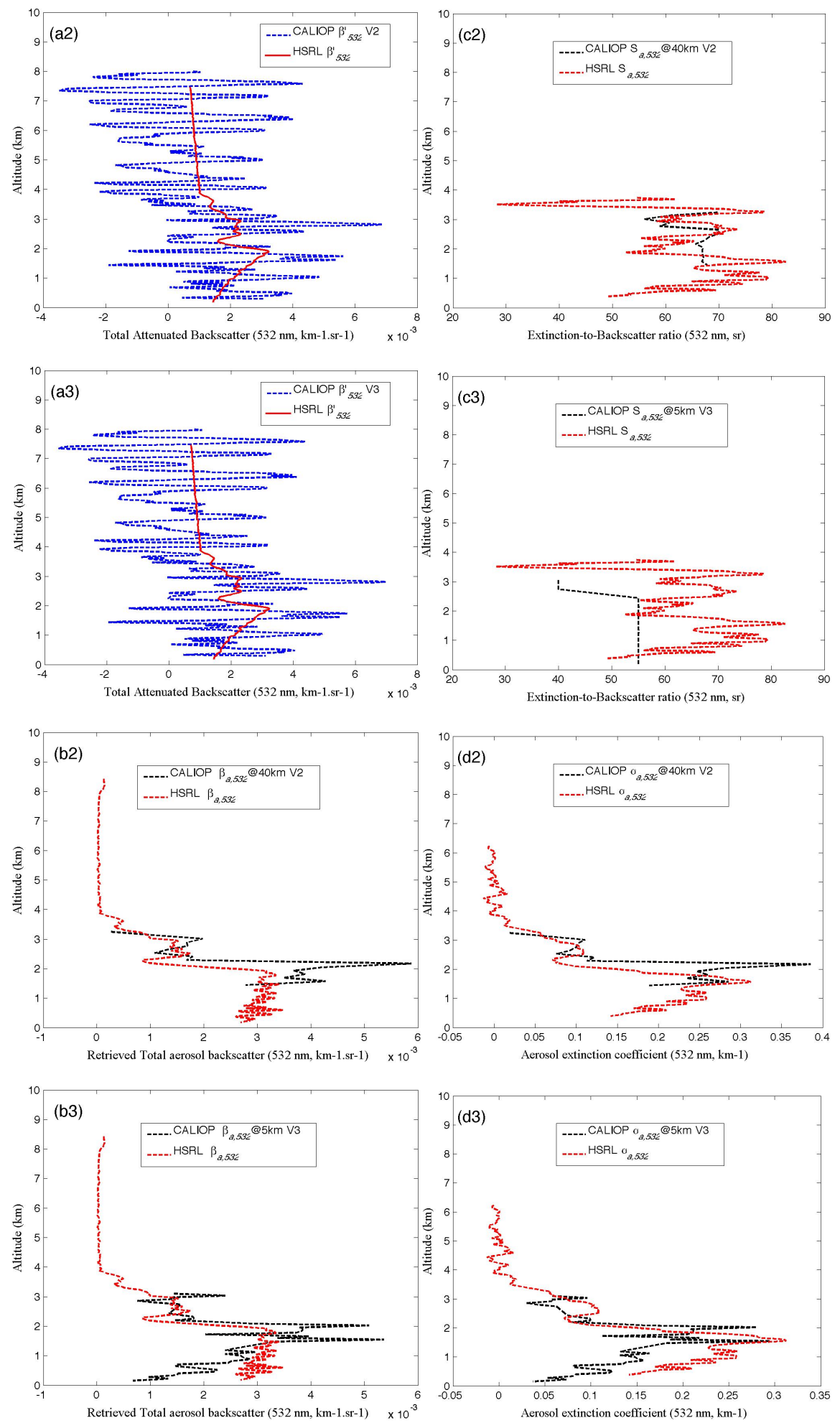

Fig. 4. 4 August 2007 - (a2) HSRL (red) and CALIOP version 2 (blue) $\beta_{532}^{\prime}$ profile, both at $\sim 4 / 3 \mathrm{~km}$ resolution, (b2) HSRL $\beta_{\mathrm{a}, 532}$ (red) and CALIOP version $2 \beta_{\mathrm{a}, 532} @ 40 \mathrm{~km}$ profile (black), c2) HSRL $S_{\mathrm{a}, 532}$ (red) and CALIOP version $2 S_{\mathrm{a}, 532} @ 40 \mathrm{~km}$ profile (black) and (d2) HSRL $\alpha_{\mathrm{a}, 532}$ (red) and CALIOP version $2 \alpha_{\mathrm{a}, 532} @ 40 \mathrm{~km}$ profile (black). All profiles are the closest to CATZ-Sanders. The CALIOP and the HSRL track are $\sim 900 \mathrm{~m}$ away from each other and the HSRL overpass is $\sim 30$ min early (17:52 UTC) compared to CALIOP (18:27 UTC); (a3) through (d3) are the same as (a2) through (d2) but using version 3 for all CALIOP profiles. 
the lowest few hundred meters close to the ground up to $1.9 \mathrm{~km}$. Although the corresponding CALIOP profile starts around $1.4 \mathrm{~km}$ and misses a lot of the aerosol signal observed by the HSRL, it seems to pick up the lowest peak with an overestimation of $1 \times 10^{-3} \mathrm{~km}^{-1} \mathrm{sr}^{-1}$ at $1.9 \mathrm{~km}$ before a maximum of $5.9 \times 10^{-3} \mathrm{sr}^{-1} \mathrm{~km}^{-1}$ at $2.2 \mathrm{~km}$. According to Table 4, the standard CALIOP version 2 aerosol @ $5 \mathrm{~km}$ products define the lowest aerosol layer (detected with a horizontal averaging of $80 \mathrm{~km}$ ) as being located between 1.5 and $2.5 \mathrm{~km}$, and composed of dust aerosol particles (CALIOP model $S_{\mathrm{a}}=40 \mathrm{sr}$ ).

The presence of either polluted dust or pure dust aerosol particles as detected in the version 2 CALIOP retrieval algorithm is unlikely according to the findings of Sect. 3.1. Indeed, the optical and microphysical properties of the aerosol plume over CATZ-Sanders tend to show a predominance of fine and strong light absorbing particles, possibly coming from a mix of haze and biomass burning particles.

In summary, Fig. 4b2 shows fairly good agreement between the HSRL $\beta_{\mathrm{a}, 532}$ and CALIOP version 2 $\beta_{\mathrm{a}, 532} @ 40 \mathrm{~km}$ profiles, except for a lack of CALIOP values below $\sim 1.4 \mathrm{~km}$ and a strong peak in the CALIOP $\beta_{\mathrm{a}, 532}$ signal around $2.2 \mathrm{~km}$. The immediate reasons could be that (i) CALIOP, with its low SNR, cannot detect tenuous aerosol layers or reach all the way down to the lidar-detected surface due to aerosol attenuation and (ii) there is a significant bug in the cloud-screening algorithm, that could explain the disparity between CALIOP and HSRL $\beta_{\mathrm{a}, 532}$ around $2.2 \mathrm{~km}$ (corresponding to the height at which a cloud is reported in Fig. 3a).

Figure $4 \mathrm{c} 2$ compares the CALIOP version $2 S_{\mathrm{a}, 532}$ $@ 40 \mathrm{~km}$ profile $\left(=\alpha_{\mathrm{a}, 532} @ 40 \mathrm{~km} / \beta_{\mathrm{a}, 532} @ 40 \mathrm{~km}\right.$, see Table 1) with the measured HSRL $S_{\mathrm{a}, 532}$ profile (see Table 2). For HSRL, $S_{\mathrm{a}, 532}(z)$ is simply the ratio of $\alpha_{\mathrm{a}, 532}(z)$ and $\beta_{\mathrm{a}, 532}(z)$, where both quantities are measured directly by the instrument. The random uncertainty for the HSRL $S_{\mathrm{a}}$ values are determined using the same methodology as presented in Hair et al. (2008). For the profile in plot 4c2, the uncertainty in $S_{\mathrm{a}}$ is less than $20 \%$ (above $1 \mathrm{~km}$ ) except at the very top of the profile $(>3 \mathrm{~km})$ where the aerosol loading approaches zero and hence relative errors are large. The increased uncertainties in this case study are somewhat larger than those presented previously (Hair et al., 2008) due to the relatively high AOD (0.52) and the presence of clouds in the sampling interval. Applying the requisite cloud clearing for this case leads to fewer raw HSRL profiles being averaged, which in turn reduces the SNR of the averaged HSRL $S_{\mathrm{a}}$ profile (see Sect. 2.3). As a consequence, the HSRL $S_{\mathrm{a}}$ variability in Fig. $4 \mathrm{c} 2$ should not be attributed solely to the natural variability of aerosols. The CALIOP retrieval algorithm does not assume a profile of $S_{\mathrm{a}}$ values but assumes, instead, a single $S_{\mathrm{a}}$ value for each detected aerosol layer in the vertical. The fact that the $S_{\mathrm{a}, 532} @ 40 \mathrm{~km}$ profile in Fig. 4c2 varies in the vertical is due to the averaging of aerosols that were identified as different types and detected at different horizontal scales. Although CALIOP and HSRL show similar averaged $S_{\mathrm{a}}$ values in the vertical ( $66 \mathrm{sr}$ for CALIOP compared with $64 \mathrm{sr}$ for the HSRL), CALIOP shows a much smaller range of $S_{\mathrm{a}, 532} @ 40 \mathrm{~km}$ (from 56 to $70 \mathrm{sr}$ ) compared with the HSRL (from 53 to 83 sr between 3.2 and $1.4 \mathrm{~km}$ ). The reason is that the range of different $S_{\mathrm{a}}$ values attainable in the CALIOP automated algorithm is much smaller than in reality. This observation leads to the introduction of a third potential explanation for the discrepancies between CALIOP and the HSRL extinction observations: (iii) the "assumed" CALIOP $S_{\mathrm{a}, 532}$ value for each aerosol layer detected in the vertical could be erroneous and shows less variability than in reality.

The small variation of the CALIOP $S_{\mathrm{a}, 532} @ 40 \mathrm{~km}$ profile in Fig. 4c2 explains the strong resemblance of the CALIOP $\beta_{\mathrm{a}, 532} @ 40 \mathrm{~km}$ and $\alpha_{\mathrm{a}, 532} @ 40 \mathrm{~km}$ profiles in Fig. $4 \mathrm{~b} 2$ and d2. The HSRL $\alpha_{a, 532}$ profile in Fig. $4 \mathrm{~d} 2$ clearly shows an increase in the extinction coefficient values between 2.4 and $3 \mathrm{~km}$, followed by a stronger peak extending from $\sim 2 \mathrm{~km}$ down to a few hundred meters close to the ground. On the other hand, the CALIOP $\alpha_{\mathrm{a}, 532} @ 40 \mathrm{~km}$ profile reports the uppermost increase higher than for the HSRL with an approximate difference of $500 \mathrm{~m}$ in the vertical and seems to pick up $\sim 500 \mathrm{~m}$ of the lowest aerosol peak (between 1.4 and $1.9 \mathrm{~km})$.

To summarize, there are several important dissimilarities between the CALIOP version 2 and the HSRL extinction coefficient profiles on 4 August 2007. The potential reasons for those discrepancies are investigated in the remainder of this study. We also investigate whether these factors have been addressed in the version 3 CALIOP extinction product.

\subsubsection{CALIOP's detection of tenuous aerosol layers and signal attenuation}

We attempt to estimate the impact of failed detection of low-level aerosol layers due to high signal attenuation on column AOD, using the collocated HSRL $\alpha_{\mathrm{a}, 532}$ profile of Fig. $4 \mathrm{~d} 2$ (red). The integration of the HSRL $\alpha_{\mathrm{a}, 532}$ profile from the ground to the base of the lowest layer detected by CALIOP (leading to an AOD of 0.23 from a few hundred meters to $1.5 \mathrm{~km}$ ), and again beginning above the top of the highest layer detected by CALIOP (AOD of 0.01 from $3 \mathrm{~km}$ to the top) adds a total of 0.24 to the standard CALIOP AOD of 0.32. This would, at least, account for the amount of extinction needed for CALIOP to be consistent with the AERONET AOD range $1 / 2 \mathrm{~h}$ around the overpass (0.48 to 0.73 ) on 4 August 2007. Based on the strong MODIS AOD underestimation $(\sim 66 \%)$ by version 2-CALIOP derived AOD we have observed (results not shown here) over the continental Eastern United States during the summer of 2007, we speculate that this is not just a problem specific to our case study but instead, may occur on larger space and time scales. Indeed, the CALIOP team has developed an alternative retrieval philosophy for low-lying aerosol layers. In 
Table 4. 4 August 2007 - Version 2 and version 3 CALIOP $5 \mathrm{~km}$-aerosol layer products (layer top and base altitude, averaging required to detect each layer, layer feature sub-type classification and quality assurance) for the closest $5 \mathrm{~km}$-profile to CATZ-Sanders along the CALIOP track.

\begin{tabular}{lll}
\hline CALIOP aerosol @ 5 km & version 2 & version 3 \\
\hline [Layer Top-Layer Base] $(\mathrm{km})$ & {$[3.1-2.7][2.5-1.5]$} & {$[3.1-2.7][2.5-1.5][1.3-0.2]$} \\
Averaging for layer detection $(\mathrm{km})$ & 802080 & 802080 \\
Layer feature sub-type classification & dust polluted-dust & dust polluted-dust polluted-dust \\
Layer feature sub-type QA & high high & high high low \\
Initial layer lidar ratio $(532 \mathrm{~nm}, \mathrm{sr})$ & 4065 & 405555 \\
\hline
\end{tabular}

those cases where transparent aerosol layers are detected, if (a) the initial estimate of layer base is "close to" the Earth's surface, and (b) the surface is reliably detected, and (c) the mean attenuated backscatter between the initial base estimate and the surface is positive, the layer base estimate is revised downward to a new, lower altitude very near the surface. This new scheme has been implemented in version 3 data products, and preliminary results suggest that it will have the desired effects (Vaughan et al., 2010).

Concerning the version 3 CALIOP algorithm, the very first result relevant to this section is the presence of aerosols below $1.9 \mathrm{~km}$ in Fig. 4b3, c3 and d3, compared to no detection of the lowest aerosol layer for CALIOP version 2 in Fig. 4b2, c2 and d2. This is confirmed in Table 4 by an additional aerosol layer close to the Earth's surface (between 1.3 and $0.2 \mathrm{~km}$ ) in the CALIOP version 3 aerosol @ $5 \mathrm{~km}$ products. From $1.9 \mathrm{~km}$ down to $\sim 700 \mathrm{~m}$, CALIOP version $3 \beta_{\mathrm{a}, 532} @ 5 \mathrm{~km}$ (Fig. 4b3) stays within $\pm 1 \times 10^{-3} \mathrm{~km}^{-1} \mathrm{sr}^{-1}$ of the HSRL $\beta_{\mathrm{a}, 532}$ profile, with the exception of a strong signal of $5.4 \times 10^{-3} \mathrm{~km}^{-1} \mathrm{sr}^{-1}$ at $\sim 1.5 \mathrm{~km}$. Underneath $1.4 \mathrm{~km}$, CALIOP version $3 \beta_{\mathrm{a}, 532} @ 5 \mathrm{~km}$ underestimates the HSRL $\beta_{\mathrm{a}, 532}$ profile by up to $\sim 2 \times 10^{-3} \mathrm{~km}^{-1} \mathrm{sr}^{-1}$ at an altitude of $\sim 200 \mathrm{~m}$. We observe an overall better agreement between CALIOP version $3 \alpha_{\mathrm{a}, 532} @ 5 \mathrm{~km}$ and HSRL $\alpha_{\mathrm{a}, 532}$ (Fig. 4d3) compared with version 2 below $1.9 \mathrm{~km}$ (Fig. 4d2).

However, the integration of $\alpha_{\mathrm{a}, 532} @ 5 \mathrm{~km}$ in the vertical yields a total column version 3 CALIOP AOD of 0.32 , equal to the version 2 CALIOP AOD in Fig. $2 b(0.32)$. In other words, applying the new layer base determination scheme used in the version 3 CALIOP retrievals does not induce any change in the total column AOD for our case study. The lack of improvement in the version 3 CALIOP AOD estimate (relative to version 2) is due to offsetting effects from other changes between version 2 and version 3, which are discussed in more detail below.

\subsubsection{CALIOP's "assumed" lidar extinction-to- backscatter ratio value per detected aerosol layer}

An alternative CALIOP version $2 \alpha_{\mathrm{a}, 532} @ 40 \mathrm{~km}^{*}$ profile was computed by applying a newly devised extinction re- trieval to all previously cloud-screened CALIOP version 2 $\beta_{532}^{\prime} @ 1 / 3 \mathrm{~km}$ profiles in the $40 \mathrm{~km}$ region of interest (such as shown in Fig. $3 b$ with a $\sim 4 / 3 \mathrm{~km}$ horizontal resolution). The alternative extinction retrieval uses a simple iterative numerical method, starting from a range $r_{0}$ (here, corresponding to an altitude of $\sim 4 \mathrm{~km}$ ) down to the ground. The aerosol extinction coefficient is assumed equal to zero at range $r_{0}$, the molecular extinction and backscatter coefficient profiles are taken from the GEOS-5 model provided in the CALIOP level 1 data, and the $S_{\mathrm{a}, 532}$ profile is taken from the closest HSRL profile to CATZ-Sanders (Fig. 4c2, red). Additional information on the alternative extinction retrieval is given in Appendix A. The alternative CALIOP AOD values along the $40 \mathrm{~km}$ segment are then obtained by integrating each alternative extinction coefficient profile in the curtain scene between $\sim 1.4 \mathrm{~km}$ and $\sim 3.2 \mathrm{~km}$, i.e., the range of CALIOP detected aerosol layers and extent of the standard CALIOP $\alpha_{\mathrm{a}, 532} @ 40 \mathrm{~km}$ profile in Fig. 4d2 (black). The result is a $40 \mathrm{~km}$-averaged alternative CALIOP version 2 AOD value of 0.44 compared to the standard CALIOP AOD value of 0.32 close to CATZ-Sanders on 4 August 2007 (Fig. 2b). It appears that, in this case study, modifying the extinction-tobackscatter ratio profile in the CALIOP extinction retrieval has less of an effect on the final AOD retrieval (adds 0.12 in the AOD) than the impact of failed detection of low-level aerosol layers due to high signal attenuation (adds 0.27 in the AOD, previous section). The conclusion of a minor impact of CALIOP's potentially erroneous "assumed" $S_{\text {a value com- }}$ pared to the inability of its signal to reach all the way down to the surface on the AOD retrieval cannot yet be stated in general. This result may, indeed, be strongly influenced by very similar averaged HSRL and CALIOP $S_{\mathrm{a}}$ values (Fig. 4c2) on 4 August 2007 close to CATZ-Sanders.

Table 4 shows no change in the version 3 aerosol sub-type classification of the two uppermost aerosol layers (dust and polluted dust). The layer close to the Earth's surface is also classified as polluted dust. Among the changes in version 3 , the extinction solver uses a different "observation-based" lidar ratio $S_{\text {a }}$ for polluted dust: $55 \mathrm{sr}$ at $532 \mathrm{~nm}$ instead of $65 \mathrm{sr}$ for version 2. Paradoxically, the use of this lower lidar ratio in the version 3 processing negates the improvements in layer optical depth that would have been expected from 


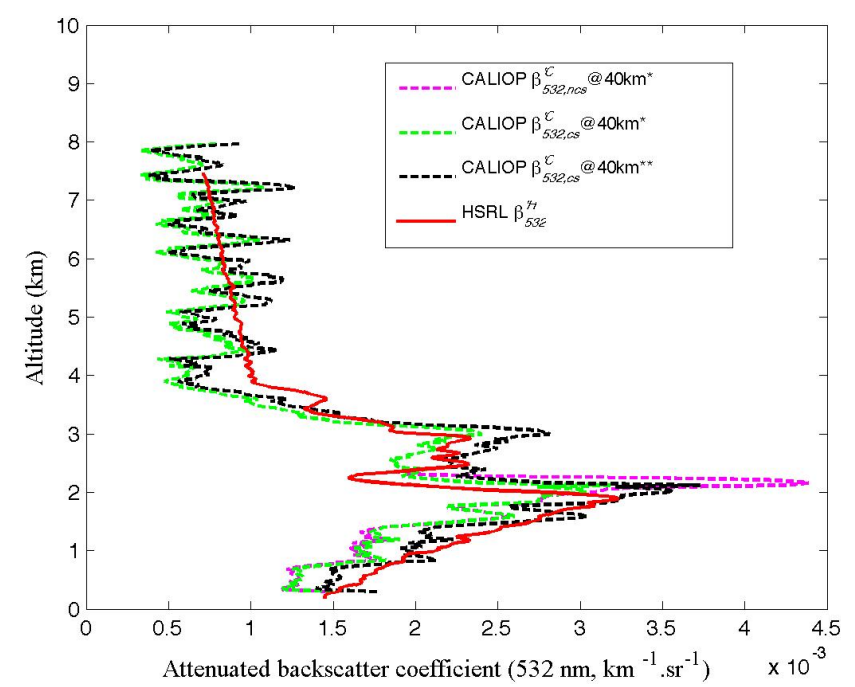

Fig. 5. 4 August 2007 -HSRL $\beta_{532}^{\prime} \mathrm{H}$ (red), alternative CALIOP version 2 non-cloud-screened $\beta_{532, n c s}^{\prime C} @ 40 \mathrm{~km}^{*}$ (magenta), alternative CALIOP version 2 cloud-screened $\beta_{532, \mathrm{cs}}^{\prime} \mathrm{C} @ 40 \mathrm{~km}^{*}$ (green), and alternative CALIOP version 2 cloud-screened normalized $\beta_{532, \mathrm{cs}}^{\prime \mathrm{C}} @ 40 \mathrm{~km}^{* *}$ profile (black); $\beta_{532, n c s}^{\prime \mathrm{C}} @ 40 \mathrm{~km}^{*}, \beta_{532, \mathrm{cs}}^{\prime \mathrm{C}}$ $@ 40 \mathrm{~km}^{*}$ and $\beta_{532, \mathrm{cs}}^{\prime} \mathrm{C} @ 40 \mathrm{~km}^{* *}$ are obtained by a sliding average of four $\beta_{532}^{\prime} @ 1 / 3 \mathrm{~km}$ profiles followed by averaging all valid profiles on the $40 \mathrm{~km}$ segment (white line in Fig. 2a); $\beta_{532, \mathrm{cs}}^{\prime} @ 40 \mathrm{~km} *$ and $\beta_{532, \mathrm{cs}}^{\prime} \mathrm{C} @ 40 \mathrm{~km}^{* *}$ are cloud-screened using the cloud @ $1 / 3 \mathrm{~km}$ product; $\beta_{532, \mathrm{cs}}^{\prime} \mathrm{C} @ 40 \mathrm{~km}^{* *}$ is normalized by the ratio of the mean HSRL $\beta_{532}^{\prime} \mathrm{H}$ and the mean $\beta_{532, \mathrm{cs}}^{\prime} \mathrm{C}$ @ $40 \mathrm{~km}^{*}$ from 4.5 to $7.5 \mathrm{~km}$ in altitude. All profiles are collocated with CATZ-Sanders.

the implementation of the revised base determination scheme (previous section).

Version 3 CALIOP $S_{\mathrm{a}, 532} @ 5 \mathrm{~km}$ (Fig. 4c3) shows less variability (numerous repetition of two values in the vertical: 40 and $55 \mathrm{sr}$ ) than version 2 (Fig. 4c2) due to less horizontal averaging (different horizontal resolution in Table 1). In addition, the vertical mean version 3 CALIOP $S_{\mathrm{a}, 532} @ 5 \mathrm{~km}$ $(\sim 52 \mathrm{sr})$ agrees less well with the mean HSRL $S_{\mathrm{a}, 532}$ value ( $\sim 64 \mathrm{sr})$ than the averaged version $2 S_{\mathrm{a}, 532} @ 40 \mathrm{~km}(\sim 66 \mathrm{sr})$. In the end, version 2 and 3 seem to show a similar classification of the aerosol type and underestimation of the corresponding lidar ratio for our case study (Table 4). The latter contributes to the underestimation of the HSRL $\alpha_{\mathrm{a}, 532}$ profile by the CALIOP version $3 \alpha_{\mathrm{a}, 532} @ 5 \mathrm{~km}$ profile in Fig. $4 \mathrm{~d} 3$.

\subsubsection{CALIOP's cloud clearing, averaging and calibration of the attenuated backscatter coefficient profile}

Figure 5 shows the closest HSRL $\beta_{532}^{\prime}$ profile (red) to CATZ-Sanders on 4 August 2007, along with three alterna- tive CALIOP version $2 \beta_{532}^{\prime}$ profiles. The first one, called $\beta_{532, \mathrm{ncs}}^{\prime} \mathrm{C} @ 40 \mathrm{~km}^{*}$ (in magenta in Fig. 5), is obtained by applying a sliding average of four $\beta_{532}^{\prime} @ 1 / 3 \mathrm{~km}$ profiles before averaging all valid profiles in the $40 \mathrm{~km}$ segment close to CATZ-Sanders (white line in Fig. 2a). The second one, called $\beta_{532, \mathrm{cs}}^{\prime \mathrm{C}} @ 40 \mathrm{~km}^{*}$ (in green in Fig. 5), corresponds spatially to the first one, but with a sliding average of four profiles on the cloud-screened $\beta_{532}^{\prime} @ 1 / 3 \mathrm{~km}$ curtain scene (Fig. 3b).

We note that the first two alternative CALIOP profiles (magenta and green, Fig. 5) show more general variability than the HSRL $\beta_{532}^{\prime} \mathrm{H}$ profile (red, Fig. 5), illustrating the differences in SNR between the two instruments, and emphasizing the utility of using a broader horizontal averaging scale of $80 \mathrm{~km}$ as the input of CALIOP's standard multi-scale averaging engine and feature detection algorithm. In addition, the comparison between CALIOP $\beta_{532 \text {,ncs }}^{\prime \text { C }} 40$ km* (magenta) and $\beta_{532, \mathrm{cs}}^{\prime} \mathrm{C} @ 40 \mathrm{~km}^{*}$ (green) confirms the presence of a reported cloud in the $40 \mathrm{~km}$ of interest around $2.2 \mathrm{~km}$ in height.

Concerning version 3, a closer look at Fig, $4 \mathrm{~b} 3$ shows a strong decrease $\left(\sim 1.4 \times 10^{-3} \mathrm{~km}^{-1} \mathrm{sr}^{-1}\right)$ in the intensity of CALIOP $\beta_{\mathrm{a}, 532} @ 5 \mathrm{~km}$ around $2.2 \mathrm{~km}$ compared

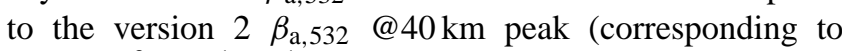
$5.9 \times 10^{-3} \mathrm{~km}^{-1} \mathrm{sr}^{-1}$ in Fig. 4b) that we presumed to be due to cloud contamination.

Two major factors need to be considered when comparing the HSRL $\beta_{532}^{\prime} \mathrm{H}$ (red) and the CALIOP $\beta_{532, \mathrm{cs}}^{\prime \prime} @ 40 \mathrm{~km}^{*}$ (green) profiles in Fig. 5. First of all, the instruments differ regarding their calibration technique and accuracy. The accuracy of the CALIOP level 1 products (and, by extension, many of the level 2 products) critically depends on the accuracy of the calibration of the attenuated backscatter profiles. The nighttime CALIOP $532 \mathrm{~nm}$ parallel attenuated backscatter measurement is calibrated by determining the ratio between the measured signal and the total backscatter estimated from an atmospheric scattering model (Powell et al., 2009; Hostetler et al., 2006; Russell et al., 1979) across an altitude range of $30-34 \mathrm{~km}$, where aerosol loading is assumed to be low and there is still sufficient molecular backscatter to produce a robust signal. Because of the degradation of the SNR in the calibration region due to noise associated with the solar background signal, the CALIOP daytime $532 \mathrm{~nm}$ calibration coefficients are interpolated from the adjacent nighttime data segments (Powell et al., 2010). On the other hand, the Airborne HSRL is internally calibrated to a high accuracy $(\sim 1-2 \%)$, and does not rely on normalization to estimated backscatter from assumed clear-air regions for calibration (Hair et al., 2008).

Secondly, the HSRL $\beta_{532}^{\prime} \mathrm{H}$ (red) and CALIOP $\beta_{532, \mathrm{cs}}^{\prime \mathrm{C}} @ 40 \mathrm{~km}^{*}$ (green) profiles differ in terms of the atmospheric attenuation of each lidar signal. The attenuation of the CALIOP profile is measured relative to the base of CALIOP's molecular normalization region at $30-\mathrm{km}$ (the minimal beam attenuation above this region is included in the calibration coefficient). Because the HSRL 
is internally calibrated, and does not rely on molecular normalization, atmospheric attenuation of the HSRL signal is measured relative to a point $1.5 \mathrm{~km}$ below the aircraft, $z_{\text {HSRL }}(\sim 7.5 \mathrm{~km})$.

For those cases where there are no clouds above the HSRL, the magnitudes of the attenuated backscatter profiles measured by the two instruments will differ by a factor of

$\Delta T^{2}=\exp \left(-2 \int_{30 \mathrm{~km}}^{Z_{\mathrm{HSRL}}}\left(\alpha_{m}\left(z^{\prime}\right)+\alpha_{\mathrm{O}_{3}}\left(z^{\prime}\right)\right) d z\right)$

so that

$\beta_{532, \mathrm{CS}}^{\prime \mathrm{C}} @ 40 \mathrm{~km}^{*}(z)=\Delta T^{2} \beta_{532}^{\prime} \mathrm{H}(z)$

Aerosol loading is considered negligible between $30-\mathrm{km}$ and $z_{\text {HSRL }}$, and thus no aerosol attenuation term is included in the calculation of $\Delta T^{2}$. The requisite values for $\alpha_{\mathrm{O}_{3}}(z)$ and $\alpha_{m}(z)$ are estimated using the gridded ozone and molecular number density profile data from the GEOS-5 analysis product available from the NASA Goddard Global Modeling and Assimilation Office (GMAO).

$\Delta T^{2}$ for the $\beta_{532, \mathrm{cs}}^{\prime \mathrm{C}} @ 40 \mathrm{~km}^{*}$ profile in Fig. 5 is 0.88 (molecular and ozone optical depth are respectively $\sim 0.04$ and $\sim 0.02$ ). Hence, if the CALIOP signal was correctly calibrated, HSRL $\beta_{532}^{\prime} \mathrm{H}$ (red) would be $\sim 12 \%$ higher than the CALIOP $\beta_{532, \mathrm{cs}}^{\prime \text { C }} @ 40 \mathrm{~km}^{*}$ (green) profile. Figure 5 shows, in fact, a general overestimation of the HSRL $\beta_{532}^{\prime}$ profile (red), especially along the uppermost and lowest intensity peak. We have computed the difference between the integrated red and green profiles of Fig. 5 as follows:

$$
\frac{\left(\int_{z=0 \mathrm{~km}}^{z=z_{\mathrm{HSRL}}} \beta_{532}^{\prime \mathrm{H}} d z-\int_{z=0 \mathrm{~km}}^{z \mathrm{HSR}} \beta_{532, \mathrm{cs}}^{\prime \mathrm{C}} @ 40 \mathrm{~km}^{*} d z\right) \times 100}{\int_{z=0 \mathrm{~km}}^{z \mathrm{HSR}} \beta_{532}^{\prime} \mathrm{H} d z}=13.74 \%
$$

The amount of overestimation of the integrated HSRL $\beta_{532}^{\prime}$ on the integrated CALIOP $\beta_{532, \mathrm{cs}}^{\prime} \mathrm{C} 40 \mathrm{~km}^{*}$ profile is similar to what would be expected in the case of a correctly calibrated CALIOP signal on 4 August 2007 near CATZSanders. Nonetheless, (Powell et al., 2010 and Rogers et al., 2011) show that, in general, the CALIOP calibration remains an issue in the version 2 level 1 attenuated backscatter products. Indeed, (Powell et al., 2010) showed that the use of a constant scaling factor to transfer calibration from nighttime to daytime measurements in the version 2 data products was precluded by thermally-induced misalignment of the transmitter and receiver, causing the daytime signal levels to vary non-linearly. In conclusion, the sub-optimal version 2 daytime calibration of CALIOP's raw signal can be added as a fourth potential reason for discrepancies between CALIOP and either HSRL or any other available AOD measurement. The next version 3 CALIOP data release improves upon this calibration scheme with significant modifications (Powell et al., 2010).

For our case study, the version 3 CALIOP cloud-screened closest $\beta_{532}^{\prime}$ profile to CATZ-Sanders in Fig. $4 \mathrm{a} 3$ shows (in blue) very little difference to the corresponding version 2 $\beta_{532}^{\prime}$ profile (Fig. 4a2) on 4 August 2007. The absolute mean difference between both version 2 and version 3 profiles is $3.4 \times 10^{-5} \mathrm{~km}^{-1} \mathrm{sr}^{-1}$ (corresponding to $\sim 4 \%$ of the mean version $3 \beta_{532}^{\prime}$ ). The absolute maximum difference between both blue profiles of Fig. $4 \mathrm{a} 2$ and a3 is $1.3 \times 10^{-4} \mathrm{~km}^{-1} \mathrm{sr}^{-1}$ $\left(\sim 14 \%\right.$ of the mean version $\left.3 \beta_{532}^{\prime}\right)$.

As a result of the different signal attenuation, in order to rigorously compare the CALIOP and HSRL total attenuated backscatter coefficients we normalized the CALIOP profile ( $\beta_{532, \mathrm{cs}}^{\prime} \mathrm{C} @ 40 \mathrm{~km}^{* *}$, in black in Fig. 5) using the ratio of the mean $\overline{\beta_{532}^{\prime} \mathrm{H}}$ by the mean $\overline{\beta_{532, \mathrm{cs}}^{\prime \mathrm{C}} @ 40 \mathrm{~km}^{*}}$ in a "clear air" region (from 4.5 to $7.5 \mathrm{~km}$ ). The normalized CALIOP $\beta_{532, \mathrm{cs}}^{\prime} \mathrm{C}\left(40 \mathrm{~km}^{* *}\right.$ (black, Fig. 5) is fairly close to the HSRL $\beta_{532}^{\prime H}$ profile (red, Fig. 5) with $\sim 93 \%$ of the differences between both profiles less than $0.5 \times 10^{-3} \mathrm{~km}^{-1} \mathrm{sr}^{-1}$. The integration of both profiles on the vertical is within $1 \%$ of each other.

We note that the normalized CALIOP $\beta_{532, \mathrm{cs}}^{\prime \text { C }} @ 40 \mathrm{~km}^{* *}$ (black) and the HSRL $\beta_{532}^{\prime} \mathrm{H}$ profile (red) should show the same trend, given that both instruments are sampling the same aerosol layer at the same wavelength. Both profiles decrease rapidly with altitude at heights below $\sim 1.9 \mathrm{~km}$, most probably due to strong aerosol attenuation. The HSRL backscatter and extinction profiles corresponding to the $\beta_{532}^{\prime} \mathrm{H}$ profile (red) are measured directly while the CALIOP backscatter and extinction profiles corresponding to $\beta_{532, \mathrm{cs}}^{\prime} \mathrm{C} @ 40 \mathrm{~km}^{* *}$ (black) are only retrieved in those regions where an aerosol layer is identified. The strong aerosol attenuation of the signal below $\sim 1.9 \mathrm{~km}$ in Fig. 5, together with the additional noise that CALIOP has to content with, is what causes the version 2 CALIOP layer detection algorithm to fail to identify the full vertical extent of the layer. This leads to a premature CALIOP apparent aerosol base height determination explaining the lack of aerosol reported below $\sim 1.4 \mathrm{~km}$ in Fig. $4 \mathrm{~b} 2$.

Figure 6 shows the comparison of the collocated HSRL (red, Fig. 5) and the renormalized CALIOP (black, Fig. 5) total attenuated backscatter coefficients from $\sim 8 \mathrm{~km}$ down to the surface close to CATZ-Sanders on 4 August 2007.

According to Fig. 6, a large number of collocated HSRL $\beta_{532}^{\prime} \mathrm{H}$ and CALIOP $\beta_{532, \mathrm{cs}}^{\prime \mathrm{C}} @ 40 \mathrm{~km}^{* *}$ coefficients are below $1.5 \times 10^{-3} \mathrm{~km}^{-1} \mathrm{sr}^{-1}(57 \%)$. CALIOP shows a fairly similar amount of those lower values of HSRL total attenuated backscatter coefficients below and above the one-to-one line with a comparable mean value of $8-9 \times 10^{-4} \mathrm{~km}^{-1} \mathrm{sr}^{-1}$. On the other hand, the overall regression line in Fig. 6 (red line, first principal component regression method (Kendall, 1957)) shows a slight CALIOP overestimation of the HSRL total attenuated backscatter coefficients. Nonetheless, after constraining the averaging, the cloud screening, and the normalization, the CALIOP level 1 attenuated backscatter measurements show good agreement with the HSRL $\beta_{532}^{\prime} \mathrm{H}$ profile 
(correlation coefficient of 0.91 , insignificant offset and a slope very close to 1$)$.

\section{Conclusion}

While first attempting to assess the general consistency between both space-borne CALIOP column integrated aerosol extinction profiles and MODIS AOD retrievals, we observed low correlation $(R \sim 0.4)$ and a general underestimation (by $66 \%$ ) of the MODIS-derived AOD by CALIOP (version 2) during Summer 2007 over the Eastern part of the United States. Both data sets are subject to retrieval error. The possible reasons for the discrepancies between both satellite retrievals as they pertain to CALIOP are discussed and explored based on a carefully selected case study containing detailed multi-sensor, multi-platform aerosol observations (ground-based AERONET sunphotometer, airborne HSRL lidar and spaceborne POLDER/PARASOL, MODIS/AQUA and CALIOP/CALIPSO). The case study is on 4 August 2007 and part of the CATZ field campaign over Maryland. On that day, we observed a consistency in the AOD values recorded by MODIS (0.67), POLDER (0.58), HSRL (0.52) and AERONET (0.48 to 0.73 ) while CALIOP was a factor of two lower $(0.32$ at $532 \mathrm{~nm})$, hence our focus on the potential shortcomings of the CALIOP data product. The study of the coincident HSRL and CALIOP profiles helps illustrate what are likely to be the most important reasons for the overall bias in the CALIOP version 2 AOD. Here we summarize these reasons and state whether they have been addressed in CALIOP version 3:

(i) CALIOP's low SNR (as shown in Figs. 3b and 4a) prevents the detection of tenuous aerosol layers. Furthermore, as shown above, the attenuation of the signal by dense aerosol plumes can drive the signal within a layer below CALIOP's detection threshold, and thus prevents identification of the full vertical extent of the layer. This explains the lack of CALIOP version $2 \beta_{\mathrm{a}, 532} @ 40 \mathrm{~km}$ data below $\sim 1.4 \mathrm{~km}$ and the premature determination of the aerosol layer base in our case study. Using the collocated HSRL layer AOD above and below the CALIOP detected aerosol layer altitudes adds a total of 0.27 to the CALIOP AOD value. CALIOP version 3 uses an alternative retrieval for low-lying aerosol layers. It revises the layer base estimate downward for certain conditions. In our case study, version 3 adds an aerosol layer close to the Earth's surface, from $1.3 \mathrm{~km}$ down to $200 \mathrm{~m}$. Both CALIOP version 3 backscatter and extinction coefficient profiles show a better agreement with the corresponding HSRL profiles. However, because the CALIOP lidar ratio is still underestimated by $~ 20 \%$ ( 55 sr vs. $\sim 70$ sr for HSRL), the CALIOP version 3 retrievals still underestimate the HSRL aerosol extinction and backscatter coefficients below $1.4 \mathrm{~km}$.

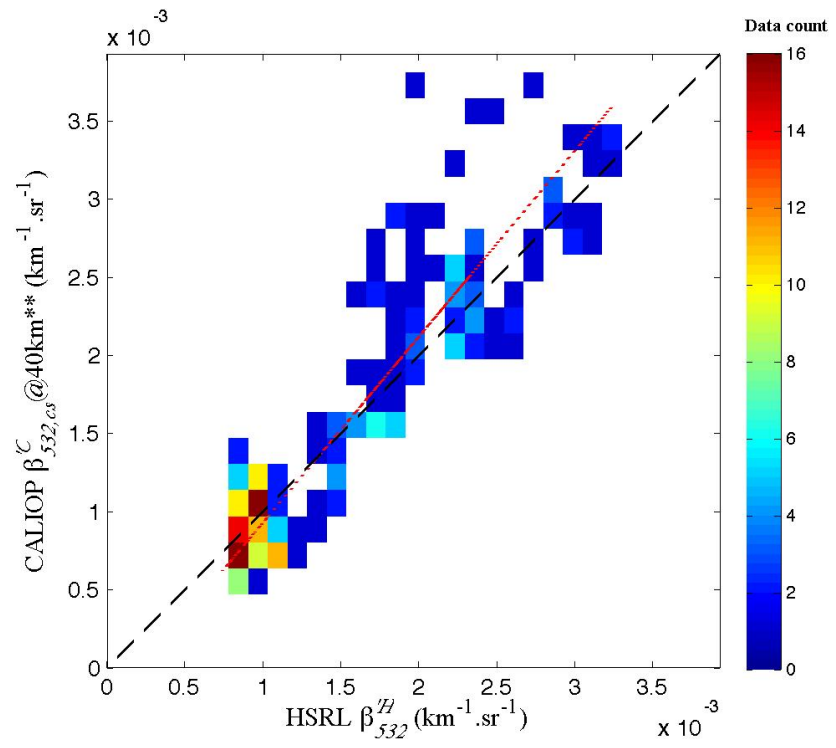

Fig. 6. 4 August 2007 - HSRL $\beta_{532}^{\prime}$ (red profile in Fig. 5) versus alternative cloud-screened normalized CALIOP version 2 $\beta_{532, \mathrm{cs}}^{\prime} \mathrm{C} 40 \mathrm{~km}^{* *}$ (black profile in Fig. 5) coefficients from $\sim 8 \mathrm{~km}$ down to the surface close to CATZ-Sanders; First principal component regression method (red line): $\beta^{\prime} \mathrm{C}_{532, C S}{ }^{* *}=(1.19 \pm 0.03)$ $\beta_{532}^{\prime} \mathrm{H}+(0.00 \pm 0.00), R=0.91, \mathrm{RMSD}=0.34 \times 10^{-3}, \mathrm{~N}=240$.

(ii) The natural variability of $S_{\mathrm{a}, 532}$ is not properly represented by the "observation-based" CALIOP $S_{\mathrm{a}, 532} @ 40 \mathrm{~km}$ profile used in the version 2 aerosol retrieval algorithm. Applying an alternative extinction retrieval to the version 2 CALIOP attenuated backscatter profiles using the independently measured HSRL lidar ratio profile adds $\sim 0.1$ to the total CALIOP AOD. The CALIOP version $3 S_{\mathrm{a}, 532} @ 5 \mathrm{~km}$ profile still shows very little variation and underestimates even more the coincident HSRL $S_{\text {a }}$ profile for our case study. The latter results from a misclassification of the aerosol type as desert dust (Initial CALIOP model $S_{\text {a }}$ of $40 \mathrm{sr}$ for both version 2 and 3 at $532 \mathrm{~nm}$ ) and polluted-dust (CALIOP model $S_{\mathrm{a}}$ of $65 \mathrm{sr}$ for version 2 and $55 \mathrm{sr}$ for version 3 at $532 \mathrm{~nm}$ ) instead of what seems to be a predominance of fine and strongly light absorbing particles, possibly coming from a mix of haze and biomass burning aerosols (with a CALIOP model $S_{\mathrm{a}}$ value of $70 \mathrm{sr}$ for version 2 and 3 ). We would like to stress the potential importance of this factor. Further investigation and validation of the CALIOP "assumed" $S_{\mathrm{a}, 532}$ product should be carried out on a broader scale and time period (i.e. measurements of $S_{\mathrm{a}, 532}$ along the CALIOP track over a large seasonal and spatial range).

(iii) There is a significant bug in the version 2 cloudscreening algorithm. This presumably explains the disparity between CALIOP and HSRL measured total 
attenuated backscatter coefficient, and in consequence, retrieved aerosol backscatter and extinction coefficient profiles around $2.2 \mathrm{~km}$ near CATZ-Sanders on 4 August 2007. The cloud contamination has the opposite effect of artificially increasing the AOD value in the general underestimation of the CALIOP AOD. This cloud contamination bug of CALIOP level 2 parameters is fixed in version 3 for our case study.

(iv) Finally, although the CALIOP signal seemed to be fairly well calibrated during our case study, it is important to mention that the version 2 CALIOP daytime calibration scheme has proven to be suboptimal, leading to bias errors in the $532 \mathrm{~nm}$ total attenuated backscatter and, in consequence, will propagate into the CALIOP aerosol extinction products (Rogers et al., 2011; Powell et al., 2010). Our case study shows very little difference between version 2 and version 3 CALIOP attenuated backscatter coefficient profiles.

Let us mention that multiple scattering, which is assumed to be negligible in the CALIOP level 2 aerosol algorithms could also be a potential reason for the extinction retrieval uncertainties. Indeed, multiple scattering effects are more significant in the case of spaceborne than airborne lidar systems due to a larger footprint. They can alter the apparent extinction or transmittance of the medium, lead to depolarization of the returned signal, and can produce stretching of the return pulse. Nevertheless, the effects of multiple scattering seem to apply mostly in the case of dense dust plumes recording high AOD values. Based on Winker et al. (2003), in the case of aerosols other than large dust particles, multiple scattering is likely to contribute, at best a $10 \%$ uncertainty to the retrieval of aerosol extinction profiles. The error introduced by ignoring multiple scattering effects is negligible compared to a fractional error of $30 \%$ in the lidar $S_{\mathrm{a}}$ ratio (resulting in an AOD fractional error of $\sim 50 \%$ when the AOD is around 0.5). In the case of fresh, dense dust layers close to the source region, the analysis of airborne in situ size distribution observations during SAMUM-1 (Saharan Mineral Dust Experiment, Southern Morocco, May-June 2006) have shown that the multiple-scattering-related underestimation of the extinction coefficient in the CALIOP lidar signals ranges from 10-40\% (Wandinger et al., 2010). On the other hand, Liu et al. (2010) shows that for moderately dense dust cases (AOD $\sim 1$ and extinction smaller than $1 \mathrm{~km}^{-1}$ ), the vertical homogeneity of the particulate depolarization ratio profile indicates negligible impact from multiple scattering. Multiple scattering effects are not considered in our paper as all the AOD observations during our case study of 4 August 2007 are below 1 .

For our case study, the version 3 total column AOD is equal to the version 2 AOD of 0.32. Having studied the different potential reasons above for a CALIOP extinction underestimation, we speculate that the effects of fixing the cloud-contamination bug (reducing the AOD) are being counterbalanced by the consequences of a downward extension of the layer base altitude for low-lying aerosols (increasing the AOD) in the version 3 aerosol extinction algorithm.

In conclusion, this study has helped illustrate potential reasons for deficiencies in the CALIOP version 2 level 2 aerosol extinction product. We hope that our study will improve the understanding of the results obtained in previous studies that have used CALIOP version 2 data. The next version of CALIOP data (version 3) includes corrections to many of the factors described above. We emphasize that, as this study is not a global validation assessment of the CALIOP version 2/version 3 aerosol extinction product, it does not provide a quantitative guidance regarding the generality and magnitude of errors likely to be present in both versions of the CALIOP extinction retrieval algorithm. This should be the object of future studies.

\section{Appendix A}

\section{Alternative CALIOP extinction retrieval}

The alternative CALIOP extinction retrieval is based on a simple numerical integration technique. Let us define:

- 0: range of the CALIOP LIDAR (corresponding to altitude $\sim 705 \mathrm{~km}$ )

$-0-r_{0}$ : range where there are no aerosols ( $\mathrm{r}_{0}$ is usually equal to $r_{\mathrm{c}}$, calibration range)

- $r$ : range of the scattering aerosol layer.

The LIDAR signal, $P(r)$, can be written as follows:

$P(r)=\frac{K}{r^{2}} \times \beta(r) \times T(0, r)^{2}=\frac{K}{r^{2}} \times \beta(r) \times T\left(0, r_{0}\right)^{2} \times T\left(r_{0}, r\right)^{2}$

where $K$ : the system constant, $r$ : the range, $\beta(r)$ : the total backscatter coefficient profile and $T(r)^{2}$ : the atmospheric two-way transmittance (i.e. the signal attenuation).

The total attenuated backscatter coefficient profile, $\beta^{\prime}(r)$, can be written as follows:

$\beta^{\prime}(r)=\beta(r) \times T\left(r_{0}, r\right)^{2}$

Substituting Eq. (A2) in Eq. (A1) leads to:

$P(r)=\frac{K}{r^{2}} \times \beta^{\prime}(r) \times T\left(0, r_{0}\right)^{2}$

The combination of Eq. (A1) and Eq. (A3) leads to:

$\beta(r) \times T(0, r)^{2}=\beta^{\prime}(r) \times T\left(0, r_{0}\right)^{2}$

with:

$T(0, r)^{2}=\exp \left[-2 \int_{0}^{r}\left(\alpha_{a}\left(r^{\prime}\right)+\alpha_{m}\left(r^{\prime}\right)\right) d r\right]$ 
$T\left(0, r_{0}\right)^{2}=\exp \left[-2 \int_{0}^{r_{0}} \alpha_{m}\left(r^{\prime}\right) d r\right]$

$\beta(r)=\beta_{a}(r)+\beta_{m}(r)$

$S_{a}(r)=\frac{\alpha_{a}(r)}{\beta_{a}(r)}$

where $\alpha_{\mathrm{a}}(r)$ and $\alpha_{m}(r)$ are the aerosol and molecular extinction coefficient profiles, $\beta_{\mathrm{a}}(r)$ and $\beta_{m}(r)$ are the aerosol and molecular backscatter coefficient profiles and $S_{\mathrm{a}}(r)$ is the extinction-to-backscatter lidar ratio.

Substituting Eqs. (A5-A8) in Eq. (A4) leads to:

$\alpha_{a}(r)=S_{a}(r) \times\left(\beta^{\prime}(r) \exp \left[2 \int_{r_{0}}^{r}\left(\alpha_{a}\left(r^{\prime}\right)+\alpha_{m}\left(r^{\prime}\right)\right) d r\right]-\beta_{m}(r)\right)$

Let us write Eq. (A9) replacing the integral by a discrete sum over different layers $i$ of range $r_{i}$ in the vertical:

$\alpha_{a}\left(r_{i}\right)=S_{a}\left(r_{i}\right) \times\left(\beta^{\prime}\left(r_{i}\right) \exp \left[2 \sum_{k=0}^{i-1}\left(\alpha_{a}\left(r_{k}\right)+\alpha_{m}\left(r_{k}\right)\right) \Delta r\right]-\beta_{m}\left(r_{i}\right)\right)$

$\alpha_{\mathrm{a}}\left(r_{i}\right)$ can then be computed using $S_{\mathrm{a}}\left(r_{i}\right)$ from the collocated HSRL instrument, $\beta^{\prime}\left(r_{i}\right)$ from the CALIOP $\beta_{532}^{\prime} @ 1 / 3 \mathrm{~km}$ profile product (cloud-screened with the CALIOP cloud @ $1 / 3 \mathrm{~km}$ product), $\beta_{m}\left(r_{i}\right)$ and $\alpha_{m}\left(r_{i}\right)$ from the gridded molecular number density profile data from the GEOS-5 analysis product available from the NASA Goddard Global Modeling and Assimilation Office (GMAO) and knowing $\Delta r$, the thickness of each layer $i$ on the vertical.

Here $r_{0}$ is where the aerosol load is assumed to be negligible and according to Eq. (A10), the aerosol extinction coefficient $\alpha_{\mathrm{a}}$ at range $r_{1}$ (first layer below $r_{0}$ ) can be computed as follows:

$\alpha_{a}\left(r_{1}\right)=S_{a}\left(r_{1}\right) \times\left(\beta^{\prime}\left(r_{1}\right) \exp \left[2 \alpha_{m}\left(r_{0}\right) \Delta r\right]-\beta_{m}\left(r_{1}\right)\right)$

Acknowledgements. The authors gratefully acknowledge the NOAA Air Resources Laboratory (ARL) for the provision of the HYSPLIT transport and dispersion model and/or READY website (http://www.arl.noaa.gov/ready.php) used in this publication and the ICARE thematic center for the provision of POLDER data. They also thank the AERONET network (especially Thomas Eck), the NASA HSRL, CALIPSO and MODIS team (especially Robert Levy) and the CNES POLDER team for their data. A special acknowledgment goes towards the UMBC lidar team and the Sunphotometer/Satellite group at NASA AMES Research Center. This research was supported by an appointment to the NASA Postdoctoral Program at the Ames Research Center, administered by Oak Ridge.

Edited by: Q. Fu

\section{References}

Anderson T. L., Charlson R. J., Winker D. M., Ogren J. A., and Holmén, K.: Mesoscale Variations of Tropospheric Aerosols, J. Atmos. Sci., 60(1), 119-136, 2003.

CALIPSO Version 2 Data Quality Statements, available online at: http://eosweb.larc.nasa.gov/PRODOCS/calipso/Quality_ Summaries/CALIOP_L2ProfileProducts_2.01.html, 2009.

Cattrall, C., Reagan, J., Thome, K., and Dubovik, O.: Variability of aerosol and spectral lidar and backscatter and extinction ratios of key aerosol types derived from selected Aerosol Robotic Network locations, J. Geophys. Res., 110, D10S11, doi:10.1029/2004JD005124, 2005.

Deuzé, J.-L., Bréon, F.-M., Devaux, C., Goloub, P., Herman, M., Lafrance, B., Maignan, F., Marchand, A., Nadal, F., Perry, G., and Tanré, D.: Remote sensing of aerosols over land surfaces from POLDER-ADEOS-1 polarized measurements, J. Geophys. Res., 106, 4913-4926, 2001.

Draxler, R. R. and Rolph, G. D.: HYSPLIT (HYbrid Single-Particle Lagrangian Integrated Trajectory) Model access via NOAA ARL READY Website: http://ready.arl.noaa.gov/HYSPLIT.php, NOAA Air Resources Laboratory, Silver Spring, MD, USA, 2010.

Dubovik, O. and M. D. King, A flexible inversion algorithm for retrieval of aerosol optical properties from Sun and sky radiance measurements, J. Geophys. Res., 105, 20673-20696, 2000 a.

Dubovik O., Smirnov A., Holben B. N., King M. D., Kaufman Y. J., Eck T. F., and Slutsker I.: Accuracy assessments of aerosol optical properties retrieved from Aerosol Robotic Network (AERONET) Sun and Sky radiance measurements, J. Geophys. Res., 105(D8), 9791-9806, 2000b.

Eck, T. F., Holben, B. N., Reid, J. S., Dubovik, O., Smirnov, A., O'Neill, N. T., Slutsker, I., and Kinne, S.: Wavelength dependence of the optical depth of biomass burning, urban and desert dust aerosols, J. Geophys. Res., 104, 3133-31350, 1999.

Gonzi, S. and Palmer, P. I.: Vertical transport of surface fire emissions observed from space, J. Geophys. Res., 115, D02306, doi:10.1029/2009JD012053, 2010.

Hair, J. W., Caldwell, L. M., Krueger, D. A., and She, C. Y.: High-spectral-resolution lidar with iodine-vapor filters: measurement of atmospheric-state and aerosol profiles, Appl. Optics, 40, 5280-5294, 2001.

Hair, J. W., Hostetler, C. A., Cook, A. L., Harper, D. B., Ferrare, R. A., Mack, T. L., Welch, W., Isquierdo, L. R., and Hovis, F. E.: Airborne high spectral resolution lidar for profiling aerosol optical properties, Appl. Optics, 47, 6734-6752, doi:10.1364/AO.47.006734, 2008.

Holben, B. N., Eck, T. F., Slutsker, I., Tanré, D., Buis, J. P., Setzer, A., Vermote, E., Reagan, J. A., Kaufman, Y. J., Nakajima, T., Lavenu, F., Jankowiak, I., and Smirnov, A.: AERONET-A federated instrument network and data archive for aerosol characterization, Remote Sens. Environ., 66, 1-16, 1998.

Hostetler, C. A., Liu, Z., Reagan, J., Vaughan, M., Winker, D., Osborn, M., Hunt, W. H., Powell, K. A., and Trepte, C.: CALIOP Algorithm Theoretical Basis Document, Calibration and level 1 Data Products, PC-SCI-201, NASA Langley Research Center, Hampton, VA 23681, USA, available online at: http://www-calipso.larc.nasa.gov/resources/project_ documentation.php, 2006.

Jones, T. A. and Christopher, S. A.: Statistical properties of 
aerosol-cloud-precipitation interactions in South America, Atmos. Chem. Phys., 10, 2287-2305, doi:10.5194/acp-10-22872010, 2010

Kaufman Y. J. and Tanré D.: Algorithm for remote sensing of tropospheric aerosol from MODIS, Product ID: MOD04, 85 pp., 1998.

Kendall M. G.: A Course in Multivariate Analysis, London, Charles W. Griffin \& Co., Ltd., 13-19, 1957.

Kim S. W., S. Berthier, J.-C. Raut, P. Chazette, F. Dulac, and S.-C. Yoon: Validation of aerosol and cloud layer structures from the space-borne lidar CALIOP using a ground-based lidar in Seoul, Korea, Atmos. Chem. Phys., 8, 3705-3720, doi:10.5194/acp-83705-2008, 2008.

Kittaka, C., Winker, D., Omar, A., Liu, Z., Vaughan, M., and Trepte, C.: Global Aerosol Distributions Derived From the CALIPSO Observations, Eos Trans. AGU, 89(53), Fall Meet. Suppl., Abstract A41A-0078, 2008.

Kuhlmann, J. and Quaas, J.: How can aerosols affect the Asian summer monsoon? Assessment during three consecutive premonsoon seasons from CALIPSO satellite data, Atmos. Chem. Phys., 10, 4673-4688, doi:10.5194/acp-10-4673-2010, 2010

Levy, R. C., Remer, L. A., Kleidman, R. G., Mattoo, S., Ichoku, C., Kahn, R., and Eck, T. F.: Global evaluation of the Collection 5 MODIS dark-target aerosol products over land, Atmos. Chem. Phys., 10, 10399-10420, doi:10.5194/acp-10-10399-2010, 2010.

Liu, Z., Winker D. M., Omar A. H., et al.: Effective lidar ratios of dense dust layers over North Africa derived from the CALIOP measurements, J. Quant. Spectrosc. Rad., doi:10.1016/j.jqsrt.2010.05.006, 2010.

Liu Z, Winker D., Omar A., Vaughan M., Trepte C., Hub Y., Powell K., Sun W., and Lin B.: Effective lidar ratios of dense dust layers over North Africa derived from the CALIOP measurements, J. Quant. Spectrosc. Rad., 112(2), 204-213,, doi:10.1016/j.jqsrt.2010.05.006, 2010.

Mamouri R. E., Amiridis, V., Papayannis, A., Giannakaki, E., Tsaknakis, G., and Balis, D. S.: Validation of CALIPSO spaceborne-derived attenuated backscatter coefficient profiles using a ground-based lidar in Athens, Greece, Atmos. Meas. Tech., 2, 513-522, doi:10.5194/amt-2-513-2009, 2009.

McGill, M. J., Hlavka, D. L., Hart, W. D., Welton, E. J., and Campbell, J. R.: Airborne lidar measurements of aerosol optical properties during SAFARI-2000, J. Geophys. Res., 108(D13), 8493, doi:10.1029/2002JD002370, 2003.

McGill, M. J., Vaughan, M. A., Trepte, C. R., Hart, W. D., Hlavka, D. L., Winker, D. M., and Kuehn, R.: Airborne validation of spatial properties measured by the CALIPSO lidar, J. Geophys. Res., 112, D20201, doi:10.1029/2007JD008768, 2007.

McMillan, W. W., Pierce R. B., Sparling L. C., Osterman G., McCann K., Fischer M. L., Rappenglck B., Newsom R., Turner D., Kittaka C., Evans K., Biraud S., Lefer B., Andrews A., and Oltmans S.: An observational and modeling strategy to investigate the impact of remote sources on local air quality: A Houston, Texas, case study from the Second Texas Air Quality Study (TexAQS II), J. Geophys. Res., 115, D01301, doi:10.1029/2009JD011973, 2010.

Mona L., Pappalardo, G., Amodeo, A., D’Amico, G., Madonna, F., Boselli, A., Giunta, A., Russo, F., and Cuomo, V.: One year of CNR-IMAA multi-wavelength Raman lidar measurements in coincidence with CALIPSO overpasses: Level 1 products com- parison, Atmos. Chem. Phys., 9, 7213-7228, doi:10.5194/acp-97213-2009, 2009.

Omar, A., Winker, D., Kittaka, C., Vaughan, M., Liu, Z., Hu, Y., Trepte, C., Rogers, R., Ferrare, R., Kuehn, R., and Hostetler, C.: The CALIPSO Automated Aerosol Classification and Lidar Ratio Selection Algorithm, J. Atmos. Ocean. Tech., 26, 19942014, doi:10.1175/2009JTECHA1231.1, 2009.

Pappalardo, G., Wandinger, U., Mona, L., Wandinger, U., Mona, L., Hiebsch, A., Mattis, I., Amodeo, A., Ansmann, A., Seifert, P., Linné, H., Apituley, A., Arboledas, L. A., Balis, D., Chaikovsky, A., D’Amico, G., De Tomasi, F., Freudenthaler, V., Giannakaki, E., Giunta, A., Grigorov, I., Iarlori, M., Madonna, F., Mamouri, R., Nasti, L., Papayannis, A., Pietruczuk, A., Pujadas, M., Rizi, V., Rocadenbosch, F., Russo, F., Schnell, F., Spinelli, N., Wang, X., and Wiegner, M.: EARLINET correlative measurements for CALIPSO: First intercomparison results, J. Geophys. Res., 115, D00H19, doi:10.1029/2009JD012147, 2010.

Peyridieu, S., Chédin, A., Tanré, D., Capelle, V., Pierangelo, C., Lamquin, N., and Armante, R.: Saharan dust infrared optical depth and altitude retrieved from AIRS: a focus over North Atlantic - comparison to MODIS and CALIPSO, Atmos. Chem. Phys., 10, 1953-1967, doi:10.5194/acp-10-1953-2010, 2010.

Piironen, P. and Eloranta, E. W.: Demonstration of a high-spectralresolution lidar based on an iodine absorption filter, Opt. Lett., 19, 234-236, 1994.

Powell, K. A., Hostetler, C. A., Liu, Z., Vaughan, M. A., Kuehn, R. E., Hunt, W. H., Lee, K., Trepte, C. R., Rogers, R. R., Young, S. A., and Winker, D. M.: CALIPSO Lidar Calibration Algorithms: Part I - Nighttime $532 \mathrm{~nm}$ Parallel Channel and $532 \mathrm{~nm}$ Perpendicular Channel, J. Atmos. Ocean. Tech., 26, 2015-2033, doi:10.1175/2009-JTECHA1242.1, 2009.

Powell, K. A., Vaughan, M. A., Rogers, R. R., Kuehn, R. E., Hunt, W. H., Lee, K.-P., and Murray, T. D.: The CALIOP 532-nm Channel Daytime Calibration: Version 3 Algorithm, Proceedings of the 25th International Laser Radar Conference, 1367-1370, ISBN 978-5-94458-109-9, 2010.

Redemann, J., Zhang Q., Schmid B., Russell P. B., Livingston J. M., Jonsson H., and Remer, L. A.: Assessment of MODIS-derived visible and near-IR aerosol optical properties and their spatial variability in the presence of mineral dust, Geophys. Res. Lett., 33, L18814, doi:10.1029/2006GL026626, 2006.

Redemann, J., Vaughan, M., Shinozuka, Y., Zhang, Q., Russell, P., Livingston, J., and Remer, L.: The combined use of MODIS, CALIPSO and OMI level 2 aerosol products for calculating direct aerosol radiative effects, presentation at the combined CALIPSO-CloudSat Science Team meeting; available online at: http://cimss.ssec.wisc.edu/calipso/ meetings/cloudsat_calipso_2009/Presentations/Thur/morning/ Redemann_MODIS_CALIPSO_OMI.pdf, 2009.

Rogers, R. R., Hostetler, C. A., Hair, J. W., Ferrare, R. A., Liu, Z., Obland, M. D., Harper, D. B., Cook, A. L., Powell, K. A., Vaughan, M. A., and Winker, D. M.: Assessment of the CALIPSO Lidar $532 \mathrm{~nm}$ attenuated backscatter calibration using the NASA LaRC airborne High Spectral Resolution Lidar, Atmos. Chem. Phys., 11, 1295-1311, doi:10.5194/acp-11-12952011, 2011.

Rolph, G. D.: Real-time Environmental Applications and Display sYstem (READY) Website: http://ready.arl.noaa.gov, NOAA Air Resources Laboratory, Silver Spring, MD, USA, 2010. 
Russell, P. B., Swissler, T. J., and McCormick, M. P.: Methodology for error analysis and simulation of lidar aerosol measurements, Appl. Optics, 18, 3783-3797, 1979.

Sekiyama T. T., T. Y. Tanaka, A. Shimizu, and T. Miyoshi: Data assimilation of CALIPSO aerosol observations, Atmos. Chem. Phys., 10, p 39-49, 2010.

Anu Rani Sharma, Shailesh Kumar Kharol, Badarinath, K. V. S., and Darshan Singh: Impact of agriculture crop residue burning on atmospheric aerosol loading - a study over Punjab State, India, Ann. Geophys., 28, 367-379, doi:10.5194/angeo-28-3672010, 2010.

Shinozuka, Y., Redemann, J., Russell, P. B., Livingston, J. M., Clarke, A. D., Podolske, J. R.: Horizontal variability of aerosol optical properties observed during the ARCTAS airborne experiment, AGU, San Francisco, California, USA, 13-17 December 2010.

Smirnov, A., Holben, B. N., Kaufman, Y. J., Dubovik, O., Eck, T. F., Slutsker, I., Pietras, C., and Halthore, R.: Optical Properties of Atmospheric Aerosol in Maritime Environments, J. Atmos. Sci., 59, 501-523, 2002.

US Environmental Protection Agency, Science Algorithms of the EPA, Models-3 Community Multiscale Air Quality (CMAQ) Modeling System. EPA/600/R- 99/030, http://www.epa.gov/ asmdnerl/CMAQ/CMAQscienceDoc.html, 1999.

Vaughan, M., Powell, K., Kuehn, R., Young, S., Winker, D., Hostetler, C., Hunt, W., Liu, Z., McGill, M., and Getzewich, B.: Fully Automated Detection of Cloud and Aerosol Layers in the CALIPSO Lidar Measurements, J. Atmos. Ocean. Tech., 26, 2034-2050, doi:10.1175/2009JTECHA1228.1, 2009.

Vaughan, M., Kuehn, R., Tackett, J., Rogers, R., Liu, Z., Omar, A., Getzewich, B., Powell, K., Hu, Y., Young, S., Avery, M., Winker, D., and Trepte, C.: "Strategies for Improved CALIPSO Aerosol Optical Depth Estimates", Proceedings of the 25th International Laser Radar Conference, 1340-1343, ISBN: 978-5-94458-1099, 2010.
Vermeulen, A., Devaux C., and Herman, M.: Retrieval of the scattering and microphysical properties of the aerosols from groundbased optical measurements including polarization, I. Method, Appl. Optics, 39(33), 6207-6220, 2000.

Wandinger, U., Tesche, M., Seifert, P., Ansmann, A., Müller, D., and Althausen, D.: Size matters: Influence of multiple scattering on CALIPSO light extinction profiling in desert dust, Geophys. Res. Lett., 37, L10801, doi:10.1029/2010GL042815, 2010.

Winker, D. M., Pelon, J., and McCormick, M. P.: The CALIPSO mission: Space borne Lidar for observation of aerosols and clouds, Spie. Proc. Ser., 4893, 1-11, doi:10.1117/12.466539, 2003.

Winker, D. M., Vaughan, M. A., Omar, A., Hu, Y., Powell, K. A., Liu, Z., Hunt, W. H., and Young, S. A.: Overview of the CALIPSO mission and CALIOP data processing algorithms, J. Atmos. Ocean. Tech., 26, 2310-2323, doi:10.1175/2009JTECHA1281.1, 2009.

Yost, C. R., Minnis, P., Sun-Mack, S., Nguyen, L., and Yi, Y.: Examination of CALIPSO cloud detection in broken cloud conditions using high resolution MODIS data, CloudSat Science Team Meeting, Seattle, WA, USA, 19 August, 2008.

Young S. A.: Analysis of lidar backscatter profiles in optically thin clouds, Appl. Optics, 34, 7019-7031, 1995.

Young, S. A. and Vaughan, M. A.: The retrieval of profiles of particulate extinction from Cloud Aerosol Lidar Infrared Pathfinder Satellite Observations (CALIPSO) data: Algorithm description, J. Atmos. Ocean. Tech., 26, 1105-1119, doi:10.1175/2008 JTECHA1221.1, 2009

Yu, H., Chin, M., Winker, D. M., Omar, A. H., Liu, Z., Kittaka, C., and Diehl, T.: Global view of aerosol vertical distributions from CALIPSO lidar measurements and GOCART simulations: Regional and seasonal variations, J. Geophys. Res., 115, D00H30, doi:10.1029/2009JD013364, 2010. 